\title{
DNA Fingerprinting of Southern Mule Deer (Odocoileus hemionus fuliginatus) in North San Diego County, California (2018-19)
}

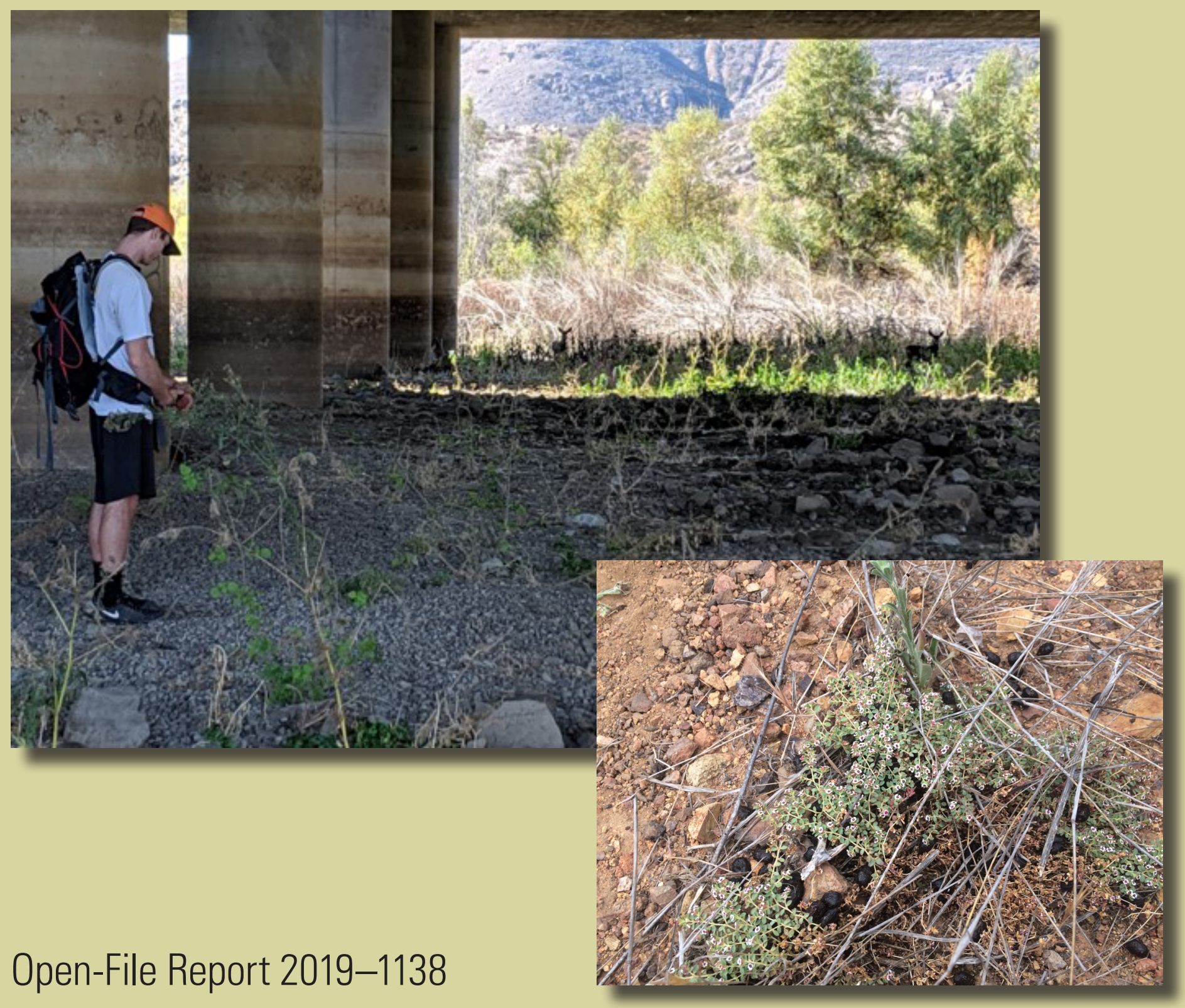

U.S. Department of the Interior

U.S. Geological Survey 
Cover: Top Left: Biological technician Ryan Buck searching for Southern mule deer scat under the Lake Hodges Bridge, in San Diego County, with mule deer in the background; photograph taken by Julia G. Smith, December 11, 2018.

Bottom Right: Fresh Southern mule deer scat pellets; photograph taken by Anna Mitelberg, May 11, 2018. 


\section{DNA Fingerprinting of Southern Mule Deer (Odocoileus hemionus fuliginatus) in North San Diego County, California (2018-19)}

By Anna Mitelberg, Julia G. Smith, and Amy G. Vandergast

Open-File Report 2019-1138 


\title{
U.S. Department of the Interior DAVID BERNHARDT, Secretary
}

\author{
U.S. Geological Survey \\ James F. Reilly II, Director
}

U.S. Geological Survey, Reston, Virginia: 2019

For more information on the USGS - the Federal source for science about the Earth, its natural and living resources, natural hazards, and the environment-visit https://www.usgs.gov or call 1-888-ASK-USGS.

For an overview of USGS information products, including maps, imagery, and publications, visit https://store.usgs.gov.

Any use of trade, firm, or product names is for descriptive purposes only and does not imply endorsement by the U.S. Government.

Although this information product, for the most part, is in the public domain, it also may contain copyrighted materials as noted in the text. Permission to reproduce copyrighted items must be secured from the copyright owner.

Suggested citation:

Mitelberg, A., Smith, J.G., and Vandergast, A.G., 2019, DNA Fingerprinting of Southern mule deer (Odocoileus hemionus fuliginatus) in north San Diego County, California (2018-19): U.S. Geological Survey Open-File Report 20191138, 25 p., https://doi.org/10.3133/ofr20191138. 


\section{Acknowledgments}

We thank the following people and the many volunteers who assisted them for their help with the 2018-19 season sample collection and (or) property access-Markus Spiegelberg, Jake Garcia, Sarah Godfrey, Brooke Prentice-Dekker, Stephen Rink (Center for Natural Lands Management); Michael Tucker and the Marine Corps Game Warden's Office (MCBCP); Charlie de la Rosa and Emily Burson (San Diego Zoo Safari Park); Leana Bulay and Jason Lopez (San Dieguito River Park); John Barone (City of San Diego); Hans Sin (California Department of Fish and Wildlife); Karla Standridge (Fallbrook Land Conservancy); James Bourdon and Pablo Bryant (Santa Margarita Ecological Reserve); Zach Principe and Trish Smith (The Nature Conservancy); Winston Vickers (University of California South Coast Research and Extension Station); Kurt Broz (Pala Environmental Department); Hannah Walchak and Ann Van Leer (Escondido Creek Conservancy); Margaret Diss, Ashley Dulaney, and Nick Sloan (San Diego

County Department of Parks and Recreation); Sarah Krejca and Austin Parker (San Diego Habitat Conservancy); Laurie Carter (Friends of Hellhole Canyon); Evelyn and Mickey Vineberg, Diane and Bryan Wold (San Diego Tracking Team); Kim Wehinger (City of San Diego Public Utilities Department); Dan Hippert (City of Escondido, Lakes and Open Space); and Jeff Anderson (Elfin Forest Recreational Reserve). We are grateful to Megan Jennings, Kristine Preston, and Carlton Rochester for their insight and advice on collection locations. 


\section{Contents}

Abstract

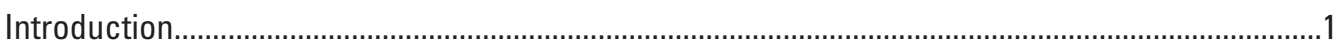

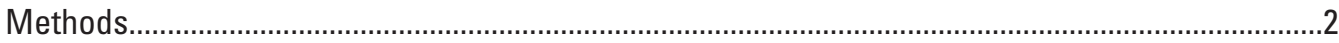

Study Site and Collections ...............................................................................................

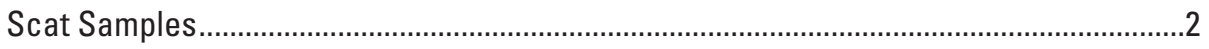

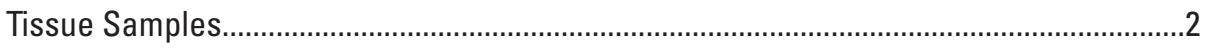

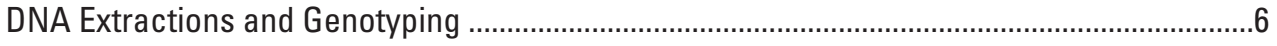

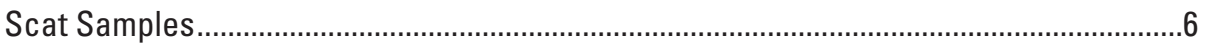

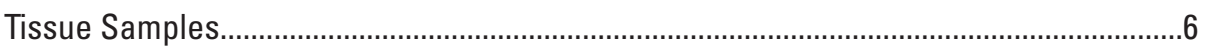

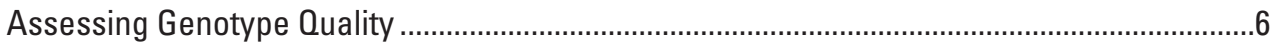

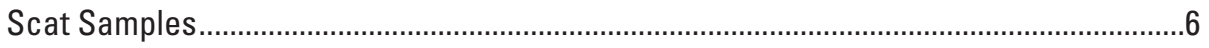

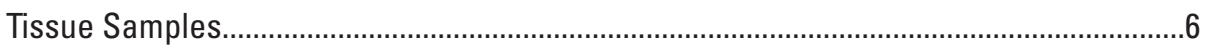

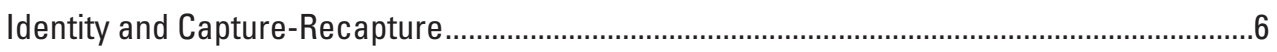

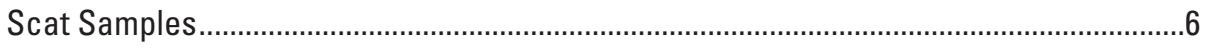

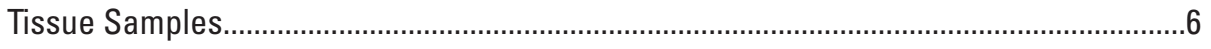

Microsatellite Statistics.....................................................................................................

North County Pedigree Analyses ......................................................................................

Regional San Diego County Population Structure and Effective Population Size ....................7

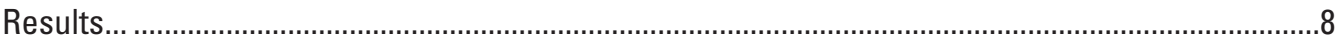

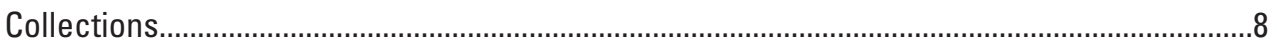

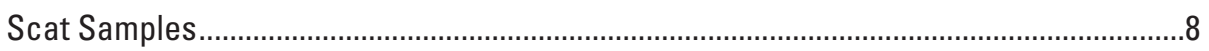

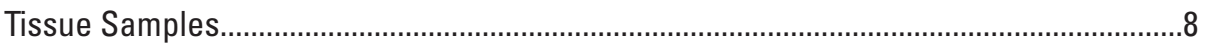

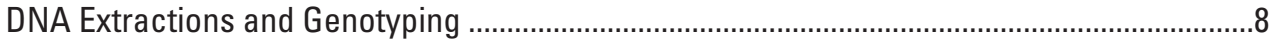

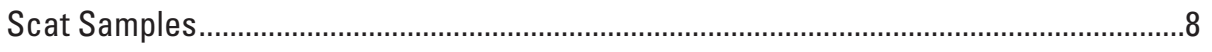

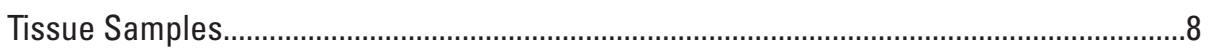

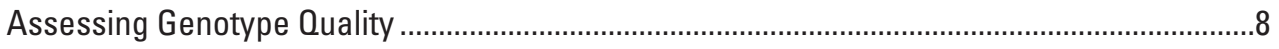

Scat Samples

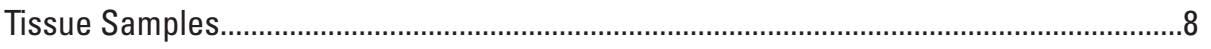

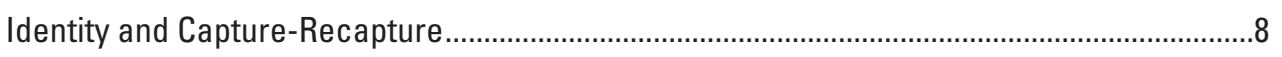

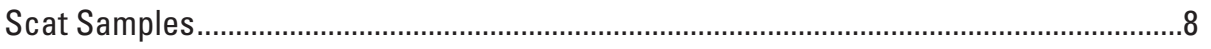

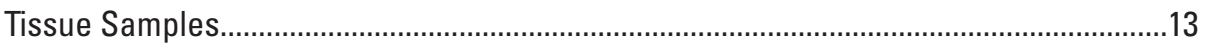

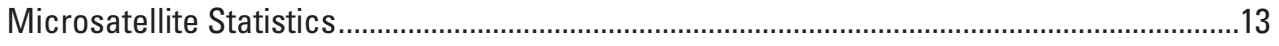

North County Pedigree Analyses ....................................................................................13

Regional San Diego County Population Structure and Effective Population Size ...................13

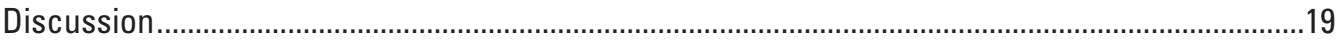

Mule Deer Movement and Connectivity in North County ......................................................19

Connectivity Within the Coastal Genetic Cluster in North County .................................19

Connectivity Within the Inland/Mountain Genetic Cluster in North County ....................19

Connectivity Between Genetic Clusters in North County ..............................................19

Regional San Diego County Mule Deer Connectivity, Diversity, and Effective

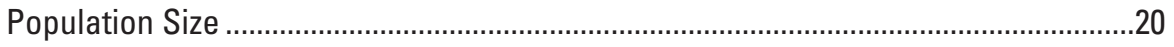

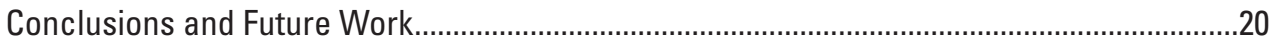

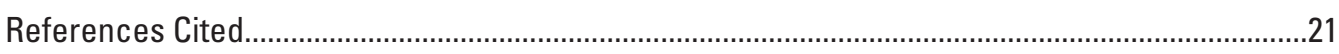

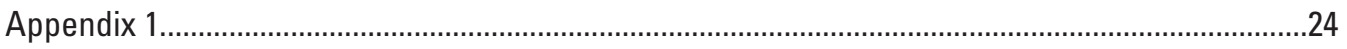




\section{Figures}

1. Map showing successfully genotyped Southern mule deer in San Diego County, California (shaded in inset) between 2005 and 2019, with individuals grouped by putative geographic populations, following criteria described in Bohonak and Mitelberg (2014).

2. Image showing four does identified moving across Melrose Drive in the Rancho La Costa Habitat Conservation Area 11

3. Image showing one buck and two does identified moving across Faraday Avenue......11

4. Image showing buck MDn069 with all capture events ...................................................12

5. Image showing buck MDn195 with all capture events .................................................12

6. Map showing full and half-sibling Southern mule deer groups identified by COLONY in the north San Diego County focus area .15

7. STRUCTURE plot for the regional San Diego County dataset ..........................................16

8. Map showing sites sampled in San Diego County between 2005 and 2019, with each pie chart representing the proportion of the site's genetic background assigned to each of two genetic clusters, as identified by STRUCTURE.

9. DAPC scatterplot of sampled Southern mule deer by discriminant analysis eigenvalues axes 1 and 2

10. DAPC scatterplot of sampled Southern mule deer by discriminant analysis (DA) 1 and DA 2

1.1. Southern mule deer tissue and scat samples obtained in 2018-19.

1.2. Finer detail of central and southern areas of fig. 8, showing the regional San Diego County STRUCTURE analysis

\section{Tables}

1. Regional sites represented by Southern mule deer successfully genotyped between 2005 and 2019 in San Diego County.

2. North San Diego County sites from which Southern mule deer scat or tissue samples were successfully obtained in 2018-19, putative geographic population, number of samples obtained, and number of samples yielding a reliable multilocus genotype

3. Fifty recaptured Southern mule deer, average Euclidean distance and range among recaptures per individual, potential roads crossed, and sampling sites

4. Microsatellite summary statistics for 14 Southern mule deer loci used for population genetic analyses

5. Family groups of Southern mule deer identified in the north San Diego County 2018-19 dataset, Euclidean distance between siblings, potential roads crossed, and whether crossing occurred across sampling sites .

6. Pairwise $\mathrm{F}_{\mathrm{ST}}$ tests performed in StrataG

7. $\mathrm{N}_{\mathrm{e}}$ (effective population size), as estimated in $\mathrm{N}_{\mathrm{e}}$ Estimator, using LD, at 0.05 frequency for the lowest allele... 


\section{Conversion Factors}

International System of Units to U.S. customary units

\begin{tabular}{lcl}
\hline \multicolumn{1}{c}{ Multiply } & By & \multicolumn{1}{c}{ To obtain } \\
\hline & Length & \\
\hline kilometer $(\mathrm{km})$ & 0.6214 & mile (mi) \\
meter $(\mathrm{m})$ & 1.094 & yard (yd) \\
\hline \multicolumn{3}{c}{ Volume } \\
\hline milliliter $(\mathrm{L})$ & 0.03381402 & ounce, fluid (fl. oz) \\
\hline
\end{tabular}

\section{Abbreviations}

A

CNLM

DA

DAPC

DNA

$\mathrm{F}_{\mathrm{ST}}$

FS

GPS

$\mathrm{H}_{\mathrm{e}}$

HCA

HS

I

k

МСВСР

MCMC

$\mathrm{N}_{\mathrm{e}}$

p

$P_{10}$

$P_{S I B}$

$\mathrm{PC}$

PCR

PO

SE

SR

USGS

v number of alleles

Center for Natural Lands Management

discriminant axis

discriminate analysis of principal components

deoxyribonucleic acid

fixation index

full siblings

Global Positioning System

expected heterozygosity

habitat conservation area

half siblings

interstate

number of assumed genetic groups

Marine Corps Base Camp Pendleton

Markov Chain Monte Carlo

effective population size

probability

probability of identity

probability of sibship

principal component

polymerase chain reaction

parent-offspring

standard error

state route

U.S. Geological Survey

version 


\title{
DNA Fingerprinting of Southern Mule Deer (Odocoileus hemionus fuliginatus) in North San Diego County, California (2018-19)
}

\author{
By Anna Mitelberg, Julia G. Smith, and Amy G. Vandergast
}

\section{Abstract}

Throughout the western United States, efforts are underway to better understand and preserve migration and movement corridors for mule deer and other big game and to minimize the impacts of development and other landuse change on populations. San Diego County is home to a unique non-migratory subspecies of mule deer, the Southern mule deer (Odocoileus hemionus fuliginatus; herein refered to as "mule deer"). Because it is the only large herbivorous mammal in San Diego, connectivity among mule deer groups is an important indicator of functional connectivity throughout San Diego County urban preserves and has therefore been monitored within central and eastern San Diego County using DNA fingerprinting since 2005. To continue this effort and to assess genetic connectivity in north San Diego County (herein "North County"), we genotyped scat samples from preserves in the area and tissue samples from Marine Corps Base Camp Pendleton. We used non-invasive capture/recapture analyses and pedigree analyses for assessing short-term movement and population clustering analyses to assess gene flow in North County. Additionally, we performed similar analyses on the combined San Diego County dataset, which was composed of the North County dataset collected for this study and a previously collected dataset from central and eastern San Diego County. Using recapture data, we found multiple instances of mule deer crossing roads in urban North County preserves, with several of these events occurring in areas where there are underpasses and culverts known to be used by mule deer. Corroborating previous studies in the region and statewide, pedigree and population structure analyses support the presence of two genetic clusters for mule deer in San Diego County - the "Coastal" and "Inland/Mountain" clusters. Low estimates of effective population size, especially in the Coastal cluster, suggest that to further understand potential vulnerabilities of mule deer in this region, it is important to continue to monitor connectivity, in particular, at the boundary between these two clusters.

\section{Introduction}

The Southern mule deer, Odocoileus hemionus fuliginatus, is one of six subspecies of mule deer in North America and is distributed in southern California, U.S.A. (fig. 1), through Baja California, Mexico. As the only large herbivorous mammal in western San Diego County (fig. 1), the Southern mule deer, herein "mule deer", occupies a unique ecological niche as a grazer and food source for mountain lions and coyotes. It is also a game species managed for hunting in portions of the county. Given these roles and its larger habitat requirements, the mule deer is considered an indicator of functional connectivity. Thus, monitoring connectivity among individual preserves within protected lands in San Diego County is of primary concern for this species (San Diego Management and Monitoring Program, 2011); indeed, the mule deer is a monitored species in several conservation plans throughout the region (City of San Diego, 2002; San Diego Association of Governments, 2003).

Several methods have been used to monitor mule deer populations in California, and San Diego County (fig. 1). These include (1) collecting radio-telemetry data (Colby, 2008), (2) conducting track and sign surveys (MarkovchickNicholls and others, 2008; City of Carlsbad, 2015),

(3) monitoring pinch points using wildlife cameras (Hayden, 2002; City of Carlsbad, 2015), (4) collecting genetic material directly from animals being handled or harvested (Pease and others, 2009), and (5) collecting genetic material from mule deer scat (that is, non-invasive methods; Valero, 2004; Mitelberg, 2010; Bohonak and Mitelberg, 2014; Mitelberg and Vandergast, 2016; Fraser and others, 2019). Genetic methods are particularly well suited for monitoring connectivity in urban landscapes for large and timid animals like mule deer. Whereas the first three approaches monitor only direct movement, population genetics analyses provide a measure of whether individuals are contributing their genes to their new territories through reproduction following movement (Schwartz and others, 2007). 
As an additional benefit, genetic sampling using scat collected from an animal's approximate range over time offers a non-invasive method for monitoring direct movement of animals (in other words, a non-invasive form of capturemark-recapture methods). Indeed, previous studies conducted in areas inhabited by mule deer in south and central San Diego County (Valero, 2004; Mitelberg, 2010; Bohonak and Mitelberg, 2014; Mitelberg and Vandergast, 2016) have shown that deoxyribonucleic acid (DNA) fingerprinting of mule deer scat can be an efficient and informative method for monitoring urban populations of mule deer in the region. These studies found population genetic structure and low levels of movement and gene flow through several areas in the region, revealing limited genetic exchange among resident groups of mule deer. Genetic connectivity appears to decline from east to west across the county and may be associated with increasing urbanization and barriers to movement along this east-west axis.

As with the rest of the county, many natural areas in north San Diego County (herein, "North County") are bordered or surrounded by urbanization. Potential barriers to mule deer movement include urban development, interstate (I) highways and state routes (SR; for example, I-15, I-5, SR-76, SR-78; appendix fig. 1.1), and heavily trafficked surface roads (for example, Rancho Santa Fe Road and Palomar Airport Road; appendix fig. 1.1). Monitoring connectivity across these potential barriers will help to elucidate their impacts on mule deer populations.

In this study, our primary objective was to assess mule deer movement and gene flow across North County. Our secondary objective was to assess mule deer population structure across the entire San Diego County region, incorporating previously collected datasets (Bohonak and Mitelberg, 2014; Mitelberg and Vandergast, 2016).

\section{Methods}

\section{Study Site and Collections}

To complement previous studies in the region (fig. 1; table 1), we focused on obtaining mule deer genetic samples from North County. We obtained both mule deer scat and tissue samples for population genetic analyses and used only the scat dataset for capture-recapture.

\section{Scat Samples}

We obtained mule deer scat samples from North County, and specifically, within or near preserves in the cities of Carlsbad, Escondido, Fallbrook, Pauma Valley, Valley Center, and Ramona (appendix fig. 1.1; table 2). Within the Carlsbad Habitat Management Plan preserve system, scat samples were collected by staff from Center for Natural Lands Management (CNLM) between April 11 and May 31, 2018, and again on February 28, 2019, by walking trails where mule deer presence has been observed (City of Carlsbad, 2015). We also obtained scat samples from the remaining sites by visiting sites within North County (between May 11, 2018, and February 28, 2019) where mule deer presence has previously been documented or by sending out collection kits to collaborators. We visually assessed scat samples for age and collected only samples that looked relatively fresh (see Bohonak and Mitelberg [2014] for details on scat age assessment). We collected and stored dry scat samples at room temperature in brown paper bags. We collected and stored moist scat samples (such as those collected very recently following defecation or during misty or rainy weather) in empty non-airtight pipette tip boxes to prevent contamination from seepage through the paper bags and to facilitate rapid drying before molding occurred. Along with sample collection date, exact Global Positioning System (GPS) data was collected for all scat samples at time of collection.

\section{Tissue Samples}

Tissue samples from Marine Corps Base Camp Pendleton (MCBCP; appendix fig. 1.1) came from animals harvested between September 3 and November 25, 2018. Samples were collected by the MCBCP game warden in screw cap tubes filled with 200-proof ethanol and stored at room temperature until we could extract DNA. Hunters self-reported the location to the MCBCP game warden by noting the kill on a map. The game warden recorded harvest date, gender, GPS coordinates (to within 100 meters of the kill). Based on location data, each sample was assigned to one of three collection sites: (1) Coastal - a coastal site dominated by coastal sage scrub, west of the Santa Margarita River and south of Basilone Road; (2) North - a northern site at higher elevation, dominated by chaparral, oak/savannah, west of the Santa Margarita River and north of Basilone Road; and (3) East - an eastern site characterized by more development, a mosaic of non-native vegetation, coastal sage scrub, and chaparral, east of the Santa Margarita River (appendix fig. 1.1; not all geographic locations labeled on map). 


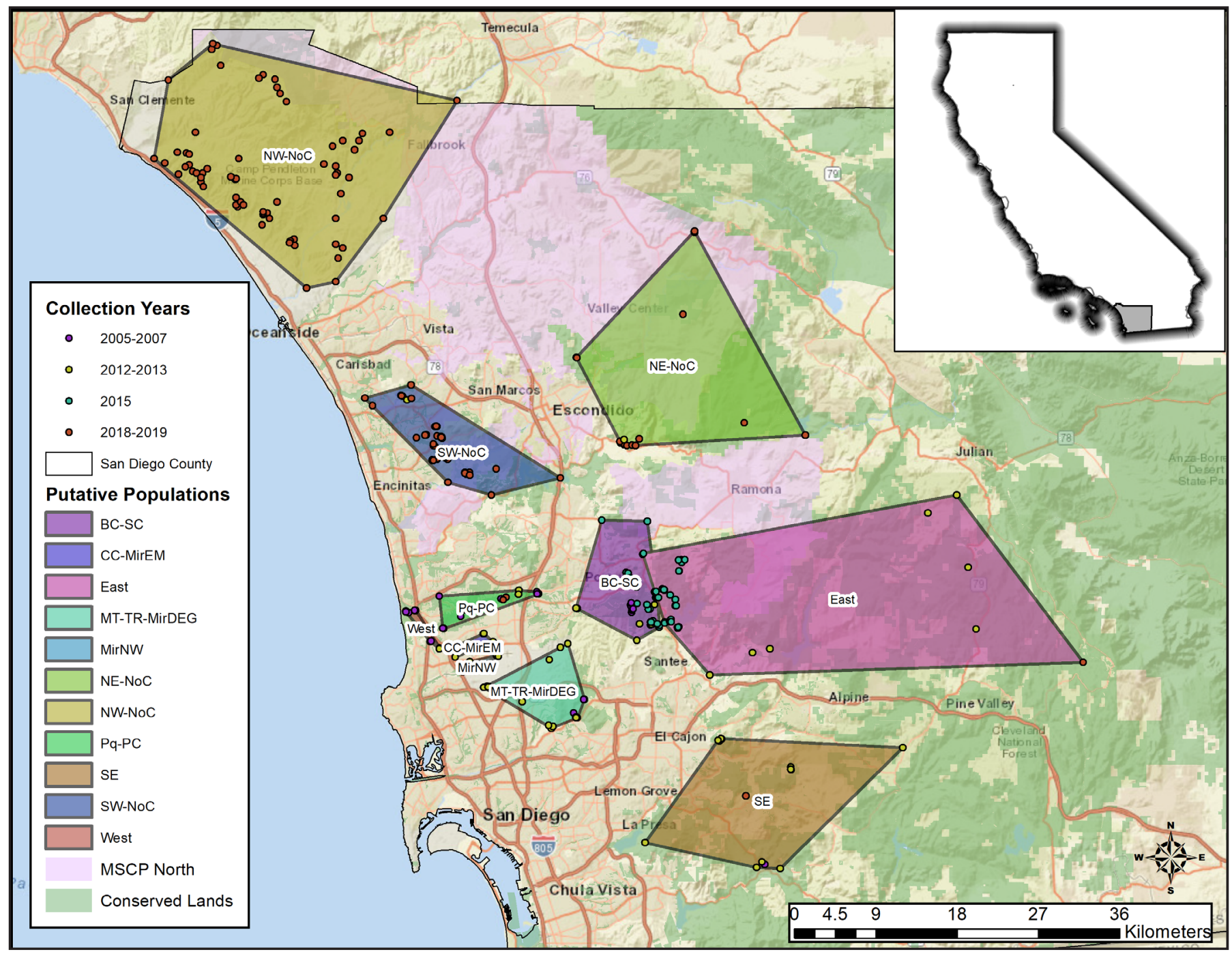

Figure 1. Successfully genotyped Southern mule deer in San Diego County, California (shaded in inset) between 2005 and 2019, with individuals grouped by putative geographic populations, following criteria described in Bohonak and Mitelberg (2014; see table 1). 
Table 1. Regional sites represented by Southern mule deer successfully genotyped between 2005 and 2019 in San Diego County.

[Sites added during 2018-19 include 1-6, 8-30, 59, and 61. Samples were also added to site 36 as part of $2018-19$ collections]

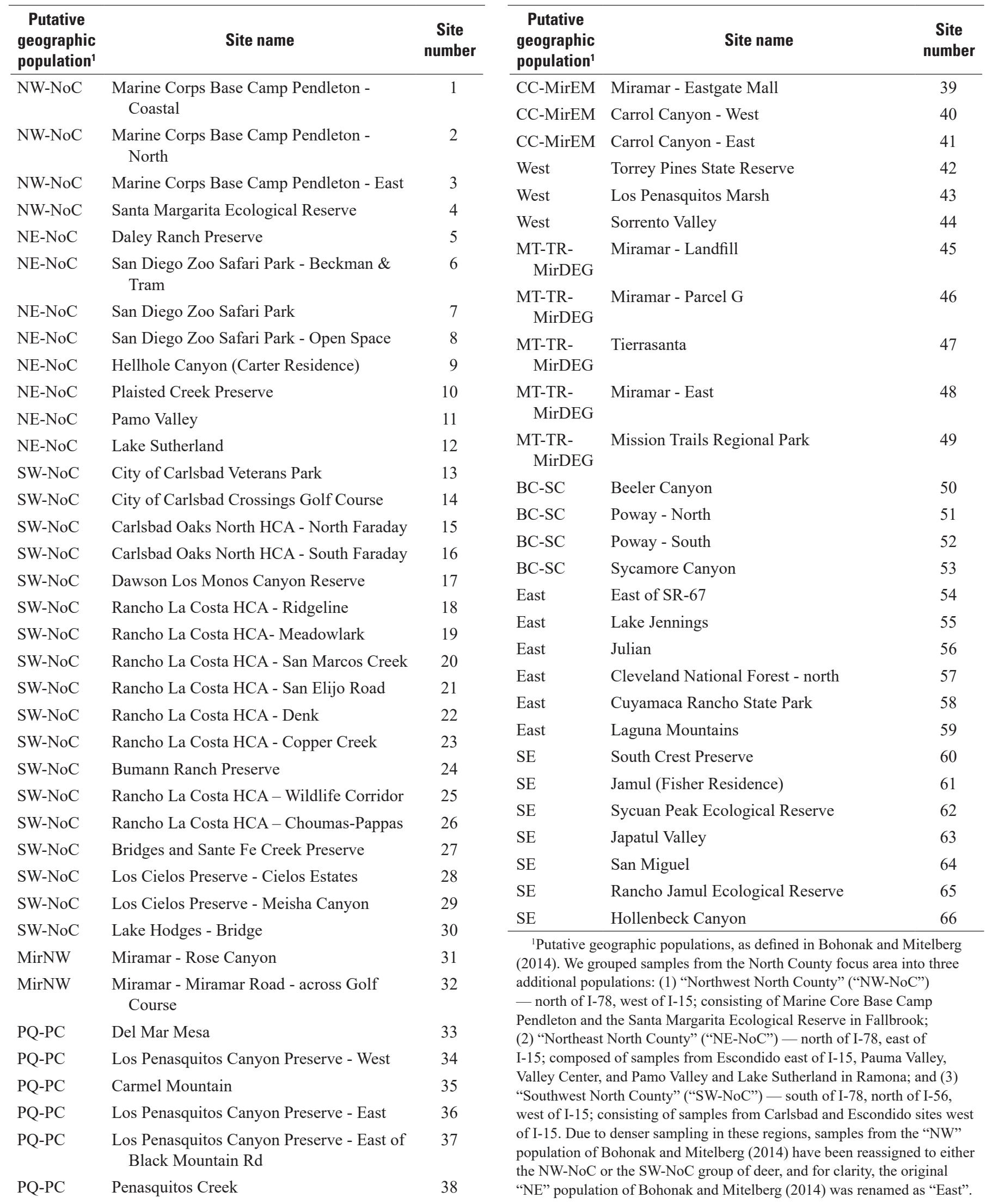


Table 2. North San Diego County sites from which Southern mule deer scat or tissue samples were successfully obtained in 2018-19, putative geographic population, number of samples obtained, and number of samples yielding a reliable multilocus genotype (defined in Bohonak and Mitelberg, 2014).

[HCA, habitat conservation area]

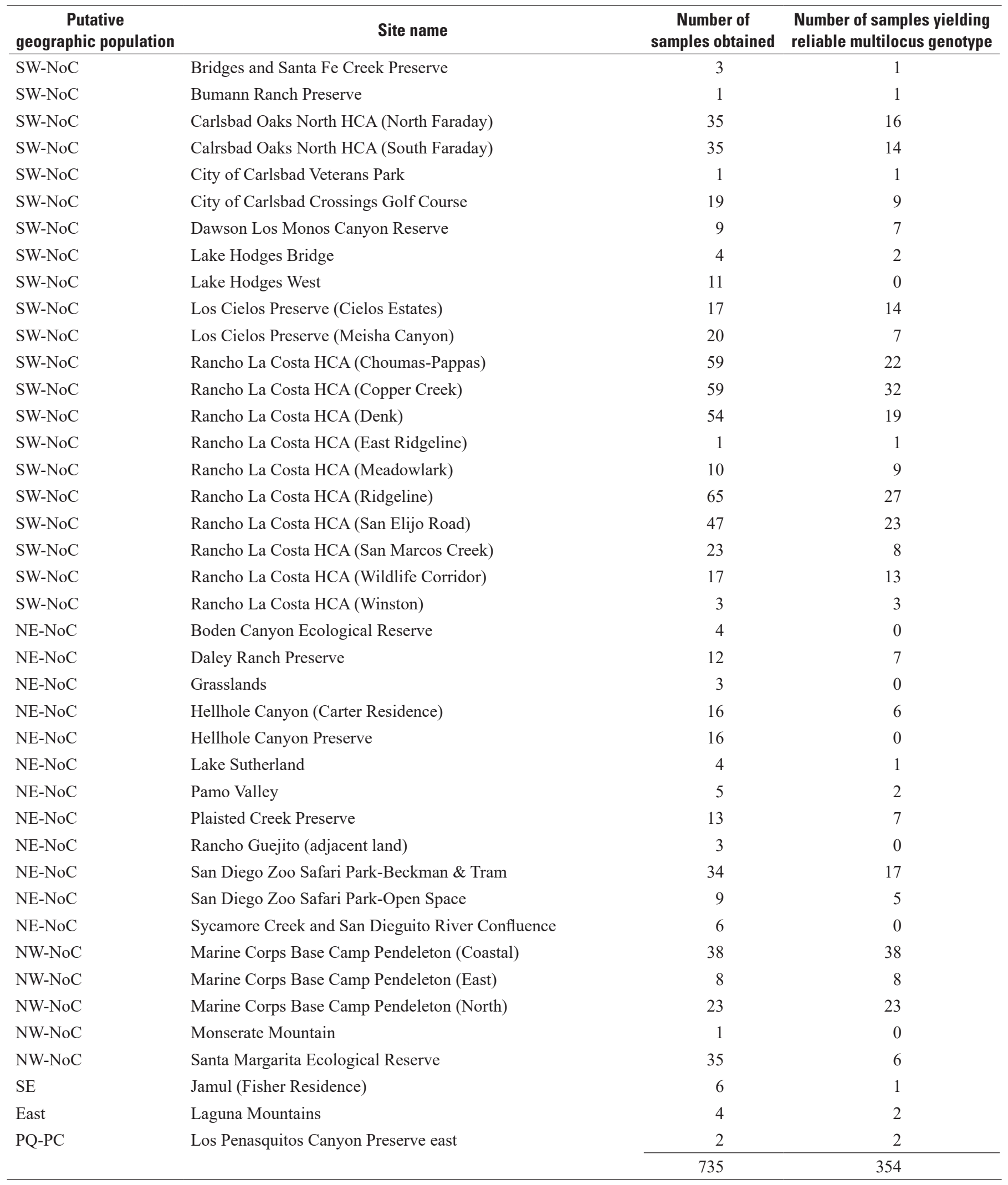




\section{DNA Extractions and Genotyping}

We extracted DNA from scat and tissue samples (extraction methods described below) and genotyped both sample types using a multiplex PCR (polymerase chain reaction) composed of 15 microsatellite loci and a sex marker (primers and conditions described in Bohonak and Mitelberg [2014]). We scored microsatellites using Genemarker version (v) 3.0.1 and binned using MsatAllele v 1.03 (Alberto, 2009).

\section{Scat Samples}

We extracted and genotyped DNA from scat piles following Bohonak and Mitelberg (2014) with a few minor modifications: (1) scat pellet surface washes were performed in a 5-milliliter $(\mathrm{mL})$ Eppendorf tube set on a lab rotator for 30 minutes, (2) PCR volume was doubled to reduce potential inhibition from contaminants in scat extractions, and (3) a single PCR and fragment analysis run was used to assess scat DNA extraction quality by visually evaluating chromatographs. From this point on, we abandoned scat samples that failed to yield a clean, scorable chromatograph in this initial genotyping attempt. For samples with a scorable chromatograph in the first genotyping run, two additional PCRs were performed, resulting in three genotyping attempts for each qualifying scat DNA extraction.

\section{Tissue Samples}

We extracted DNA from tissues obtained from the MCBCP harvest using the DNeasy Blood and Tissue extraction kit (Qiagen), following manufacturer's recommended protocol. We genotyped each tissue sample with a single PCR, with the exception of 30 percent of tissue samples that we genotyped twice to assess the quality of tissue-derived genotypes.

\section{Assessing Genotype Quality}

\section{Scat Samples}

To reduce genotyping error (Bonin and others, 2004) in the scat-derived data, we analyzed the initial three-replicate multilocus genotypes for each scat sample with RELIOTYPE (Miller and others, 2002), a software that implements a maximum likelihood algorithm to assess the reliability of the multilocus genotype based on a reference set of allele frequencies. The software also recommends a replication strategy for samples that fail to pass the 99.49 percent reliability criterion. For this analysis, we used allele frequencies from the combined Bohonak and Mitelberg (2014) and Mitelberg and Vandergast (2016) datasets. We discarded all samples for which RELIOTYPE recommended more than six PCR replicates. We genotyped samples requiring six or fewer PCR replicates again (according to RELIOTYPE recommendations) and ran these through RELIOTYPE a second time. Following these additional PCRs, we discarded all data from scat samples failing to yield a reliable genotype. We used GIMLET 1.3.3 (Valière, 2002) to reconstruct consensus genotypes (from multiple genotypes per scat pile) for all scat piles with reliable DNA fingerprints.

\section{Tissue Samples}

For tissue samples from MCBCP, we compared replicate genotypes to assess the reliability of tissue-derived genotypes. For each tissue sample, we also compared the gender assigned by PCR to the gender recorded at the time of harvest.

\section{Identity and Capture-Recapture}

\section{Scat Samples}

We identified individual mule deer from scat using GIMLET's "group by genotype" algorithm. We considered the first scat pile processed as an individual mule deer's "initial capture event" (the first time that individual was encountered). All matching scat piles collected after this capture were identified as "recapture events" (even if they occurred on the same day). We calculated the minimum, maximum, and average geographic (Euclidean) distances between all capture and recapture events in the $\mathrm{R}$ package gdistance (van Etten, 2017).

\section{Tissue Samples}

Tissue samples from MCBCP came from harvested individuals. Given the long distance between $\mathrm{MCBCP}$ and scat sampling sites (more than 8 kilometers $[\mathrm{km}]$ ), it is unlikely that harvested mule deer were also sampled earlier in the year during scat collections. To confirm this, we combined the scat and tissue datasets and used CERVUS v 3.0.7 (Kalinowski and others, 2007) to identify all individuals.

\section{Microsatellite Statistics}

We performed all analyses from this point forward on the combined dataset of mule deer identified from the scat- and tissue-derived genotypes from North County (herein "North County dataset"). We used CERVUS to (1) calculate basic microsatellite statistics, (2) detect any loci with null alleles, and (3) calculate the average probability that two unrelated individuals $\left(\mathrm{P}_{\mathrm{ID}}\right)$ or two siblings $\left(\mathrm{P}_{\mathrm{SIB}}\right)$ in the dataset could have identical genotypes. Because pedigree and population genetic analyses can be sensitive to null alleles, we eliminated loci determined by CERVUS to have null alleles from all remaining analyses. 


\section{North County Pedigree Analyses}

Family relationships can be used to complement capture/recapture data and infer long-term movement (over generations). We used the maximum likelihood pedigree reconstruction software COLONY v 2.0.6.5 (Wang, 2004; Wang and Santure, 2009; Jones and Wang, 2010) to identify potential first-order (full-siblings [FS] and parent offspring [PO] dyads) and second-order (half-sibling [HS]) relatives. We ran three repetitions of this analysis, each time with a different seed number and the following parameter options: female and male polygamy, with inbreeding, medium run length, fulllikelihood analysis method, medium likelihood precision, no sibship scaling nor sibship prior; all other parameters were set to default. We used genotyping error rates from Bohonak and Mitelberg (2014), with the exception that the minimal recommended false alleles rate of 0.0001 was assigned to all loci to avoid exclusion of parent-offspring pairs based on a single allele. We set the expected probability of detecting a father or mother to 0.05 and 0.15 , respectively. We accepted only dyads appearing in all three independent COLONY runs with $\geq 80$ percent probability of relatedness ( $\mathrm{P} \geq 0.80$; Warner and others, 2016). We calculated the geographic distance between all related dyads using ArcMap v. 10.6.1.

\section{Regional San Diego County Population Structure and Effective Population Size}

We performed all analyses from this point forward on a "regional dataset" composed of all mule deer identified in this study and the "pre-2018" dataset of 223 mule deer identified in San Diego County by Bohonak and Mitelberg (2014) and Mitelberg and Vandergast (2016). To assess population structure in San Diego County, we first used CERVUS to confirm that no individual from the pre-2018 dataset was also sampled in the present study. We then ran a COLONY pedigree analysis to identify close relatives within the regional dataset. To reduce bias associated with sampling close relatives in population structure analyses (Rodríguez-Ramilo and Wang, 2012), we excluded one individual from each related dyad proposed by COLONY; we did this randomly, with the exception that per dyad, we preferentially retained an individual if it was the sole representative of a sampling site. We performed individual-based clustering analyses on all remaining unrelated individuals throughout the region in STRUCTURE v 2.3.4 (Pritchard and others, 2000; Falush and others, 2003; $\mathrm{k}=1-10$ clusters [where $\mathrm{k}$ is the number of assumed genetic groups]; 10 replicates per k; 500,000 burn in, 500,000 MCMC [Markov Chain Monte Carlo] replicates following burnin; admixture model; correlated alpha) and compiled the replicate runs in CLUMPAK (Kopelman and others, 2015). Individual-based clustering analyses, which search for the optimal number of genetic clusters (k), were based solely on individual genotype. We performed two analyses using STRUCTURE - one without and one with a prior assignment to a putative geographic population (as defined and shown in fig. 1). We used Evanno's $\Delta \mathrm{K}$ or Pritchard's $\ln (\operatorname{Pr}(X \mid K)$ to derive the optimal number of genetic clusters (k).

Additionally, we performed a discriminant analysis of principal components (DAPC; Jombart and others, 2010) using the adegenet package (v 2.1.1; Jombart, 2008) in R 3.5.1 (R Core Development Team, 2011). The package DAPC first uses a principal components analysis to identify population combinations and minimize variation within groups (Jombart and others, 2010). These principal component (PC) eigenvalues are then used in a discriminant analysis to find the discriminant functions that maximize differences among groups while minimizing variation within groups. We used the cross-validation procedure in adegenet to determine the optimal number of PCs to retain in the DAPC analysis, using 90 percent of the dataset as a training dataset and 10 percent as a validation dataset, and performing 30 replicates at each level of PC retention. We selected the number of PCs with the lowest root mean squared error for the final analysis. Because K-means clustering did not converge on an optimal K, we performed DAPC using putative geographic populations defined in Bohonak and Mitelberg (2014; see table 1 and fig. 1), as well as the two genetic clusters detected by STRUCTURE.

To estimate the extent of population differentiation for the entire San Diego County region, we ran a series of pairwise genetic differentiation $\left(\mathrm{F}_{\mathrm{ST}}\right)$ tests using the $\mathrm{R}$ package STRATAG, with putative geographic populations as units (Archer and others, 2017). $\mathrm{F}_{\mathrm{ST}}$ is a measure of population genetic differentiation as a result of population structure (Wright, 1965), ranging from no differentiation at $\mathrm{F}_{\mathrm{ST}}=0$ to complete differentiation at $\mathrm{F}_{\mathrm{ST}}=1$. We used 10,000 permutations to test the significance of each pairwise $\mathrm{F}_{\mathrm{ST}}$ value and corrected for multiple tests using the Bonferroni correction ( $\mathrm{p}=0.00091$ for 55 tests).

To estimate the effective population size $\left(\mathrm{N}_{\mathrm{e}}\right)$ for the San Diego region, we used the linkage disequilibrium method implemented in $\mathrm{N}_{\mathrm{e}}$ Estimator (Do and others, 2014), with the lowest frequency allele level of 0.05 (to limit inflation of $\mathrm{N}_{\mathrm{e}}$ by rare alleles). We used the 95 percent confidence interval determined from permutation tests to obtain a range for the $\mathrm{N}_{\mathrm{e}}$ estimates. $\mathrm{N}_{\mathrm{e}}$ estimates were obtained for the 11 putative geographic populations; we also combined these populations into the larger regional level genetic clusters, as suggested by the STRUCTURE results, to assess $\mathrm{N}_{\mathrm{e}}$ at this regional level. 


\section{Results}

\section{Collections}

\section{Scat Samples}

We obtained 666 scat piles (table 2; appendix fig. 1.1). Of these, 437 samples (67 percent) were collected at CNLM managed properties in Carlsbad, 217 were collected from other regions in North County, and 12 samples came from San Diego County sites outside North County (Los Penasquitos Canyon Preserve, Jamul, and Laguna Mountains; these samples were only included in the regional analyses for all of San Diego County). Sampling at several sites in Fallbrook, Pauma Valley, Pala Indian Reservation, Temecula, and Rainbow were unsuccessful (appendix fig. 1.1; not all geographic locations labeled). As in previous studies in the region (Bohonak and Mitelberg, 2014, and Mitelberg and Vandergast, 2016), scat samples from the more rural eastern parts of San Diego County were more challenging to obtain, possibly because mule deer are more spread out in these areas.

\section{Tissue Samples}

We received 69 tissue samples ( 38 males and 31 females) from the 2018 harvest at MCBCP. Thirty-eight samples came from the Coastal, 23 from the North, and 8 from the East site (table 2; appendix fig. 1.1).

\section{DNA Extractions and Genotyping}

\section{Scat Samples}

We extracted and attempted to genotype all 666 scat piles at least once. Three hundred eighty (57 percent) of these scat piles yielded a scorable chromatograph in the initial genotyping attempt and qualified for further genotyping with two additional PCRs. We removed one of the 15 microsatellite loci (Locus F) from the scat dataset owing to scoring and binning inconsistencies.

\section{Tissue Samples}

We extracted DNA from 69 tissue samples and genotyped all 69 tissue samples for the 15 microsatellite loci and a gender identification marker. We scored and retained Locus F genotypes for the tissue samples because this locus amplified consistently in tissue extractions.

\section{Assessing Genotype Quality}

\section{Scat Samples}

Two hundred eighty-five scat piles ( $\sim 3$ percent of those collected and $\sim 75$ percent of those that qualified following a single genotype attempt) yielded a reliable genotype following the screening protocol implemented using RELIOTYPE; all 285 scat samples were unambiguously assigned a gender. Data from the remaining 381 scat piles were discarded from all further analyses.

\section{Tissue Samples}

We found no differences among replicate genotypes of tissue extractions. The gender assigned to each harvested mule deer based on the PCR-based gender marker matched the gender of all 69 mule deer as recorded at the time of sample collection.

\section{Identity and Capture-Recapture}

From the scat- and tissue-derived datasets collected, we identified a total of 170 individual genotypes (62 males and 108 females); 165 of these individuals came from North County ( 5 individuals came from outside our North County focus area-Jamul, Los Penasquitos Canyon Preserve, and Laguna Mountains and from this point on were included only in the regional analysis).

\section{Scat Samples}

We identified 101 individual mule deer in the scatderived dataset ( 24 males and 77 females). Fifty-one mule deer had a single capture event; 50 mule deer, including 30 does and 20 bucks, were recaptured at least once (recapture rate $=50$ percent). Recapture events per individual ranged from 1 to 21, and recapture distances ranged from 0 to 4,625 m, with an average of $353 \mathrm{~m}$ (table 3; scat piles at several sites did not have reliable GPS coordinates, and we excluded these from distance analyses). Approximately 22 percent of recaptures occurred within $100 \mathrm{~m}$ of each other, and 14 percent were recaptured more than $1 \mathrm{~km}$ apart. 
Table 3. Fifty recaptured Southern mule deer, average Euclidean distance and range among recaptures per individual, potential roads crossed, and sampling sites (if different).

[m, meter; f, female; NA, not applicable; m, male]

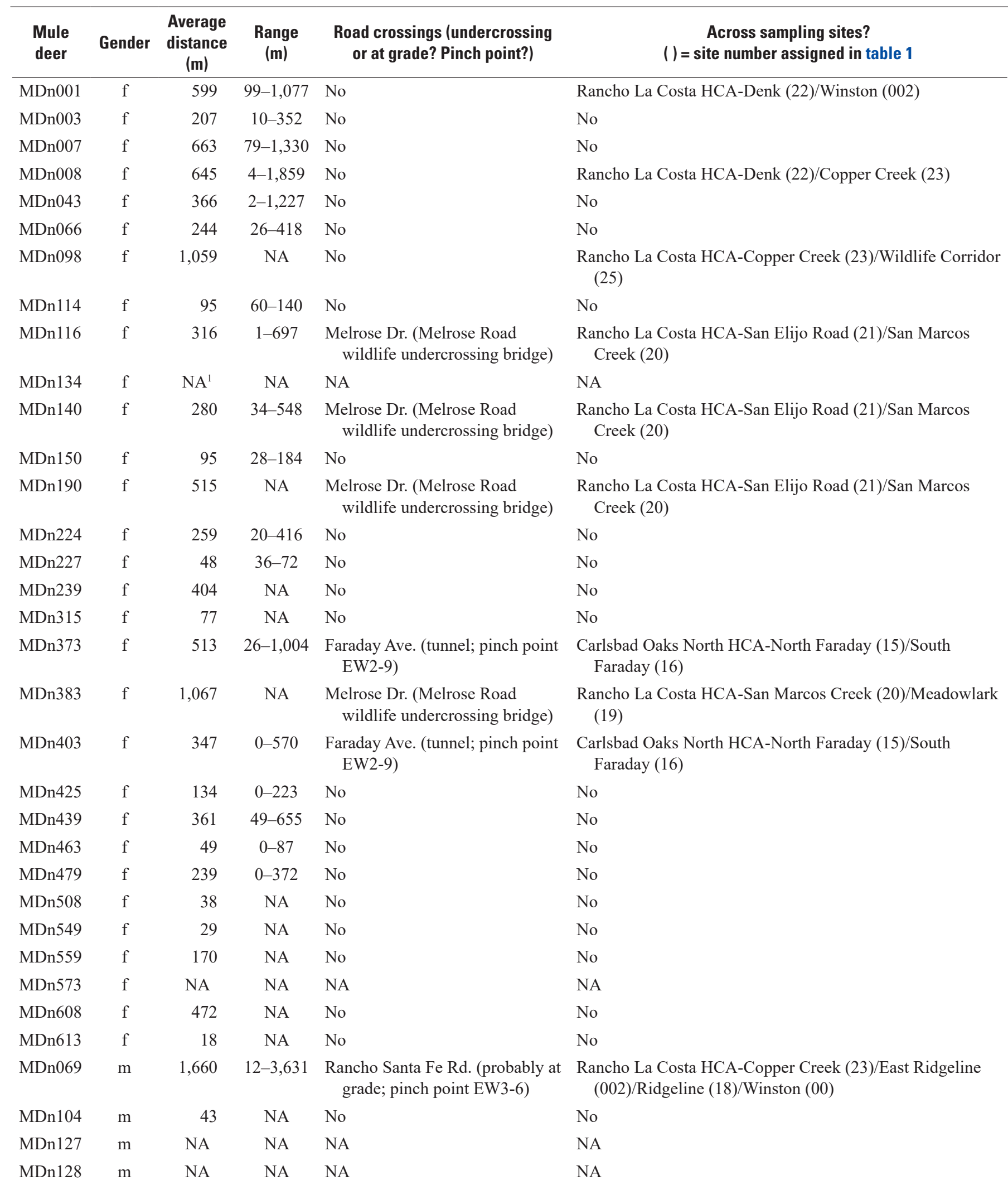


Table 3. Fifty recaptured Southern mule deer, average Euclidean distance and range among recaptures per individual, potential roads crossed, and sampling sites (if different).-Continued

[m, meter; f, female; NA, not applicable; m, male]

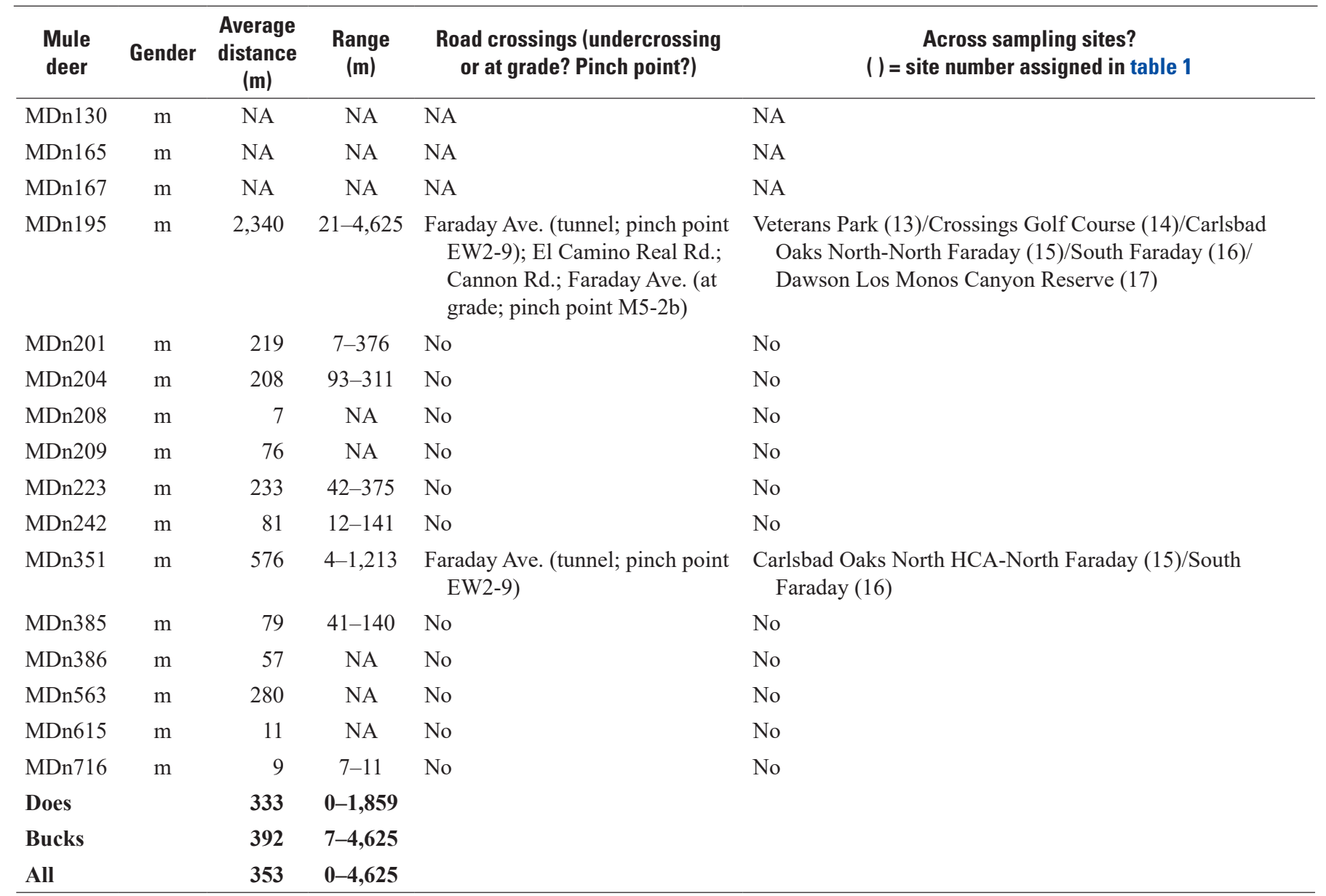

${ }^{1}$ NA Recaptured once or no distance calculated due to lack of exact GPS coordinates.

${ }^{2} 00$ Site does not have site number because all individuals collected at the site were recaptures.

We examined recapture events to obtain information on mule deer movement. All recapture events in which roads were crossed occurred in Carlsbad (table 3; figs. 2-5). Several of these recaptures occurred in areas where underpasses and culverts facilitate mule deer movement (City of Carlsbad, 2015). Four does had scat-based recaptures on both sides of Melrose Drive (table 3; fig. 2). These mule deer may have used the Melrose Drive Wildlife Undercrossing (fig. 2) to move between the San Marcos Creek and San Elijo Road sites of Rancho La Costa Habitat Conservation Area (HCA; to locate sites on map, refer to table 1 for site number, then to fig. 8 and appendix fig. 1.2). Scat from two does and one buck was found on both sides of Faraday Avenue; these animals may have used a tunnel under this road (table 3; fig. 3; pinch point EW2-9, City of Carlsbad, 2015). Previous monitoring efforts using cameras and mule deer sign surveys have shown mule deer moving through this tunnel frequently (City of Carlsbad, 2015).

We found two instances of bucks traversing relatively long distances in Carlsbad. Within a period of 13 days, scat from one buck (MDn069) was identified as far as $3.6 \mathrm{~km}$ apart in the Copper Creek, Ridgeline, and Winston sites of Rancho La Costa HCA (table 3; fig. 4). Within a period of 25 days, scat from one buck (MDn195) was captured at multiple sites as far as $4.6 \mathrm{~km}$ apart moving between Veterans Park, Crossings Golf Course, north and south of Faraday Avenue, and at the Dawson Los Monos Canyon Reserve (table 3; fig. 5). 


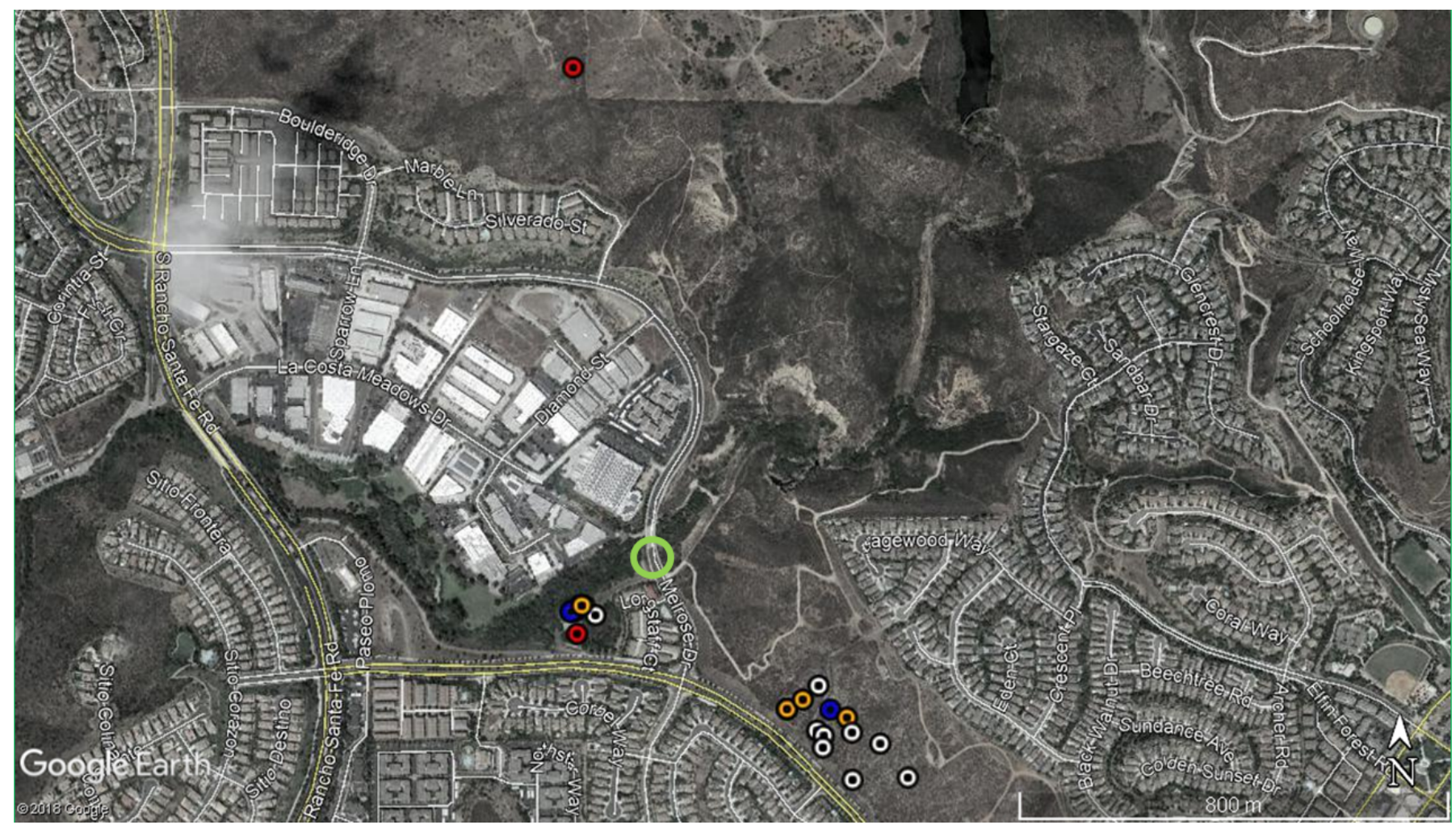

Figure 2. Four does (MDn190 [blue circles], MDn140 [orange circles], MDn383 [red circles], and MDn116 [white circles]) identified moving across Melrose Drive in the Rancho La Costa Habitat Conservation Area. Green circle = Melrose Road Wildlife Undercrossing Bridge.

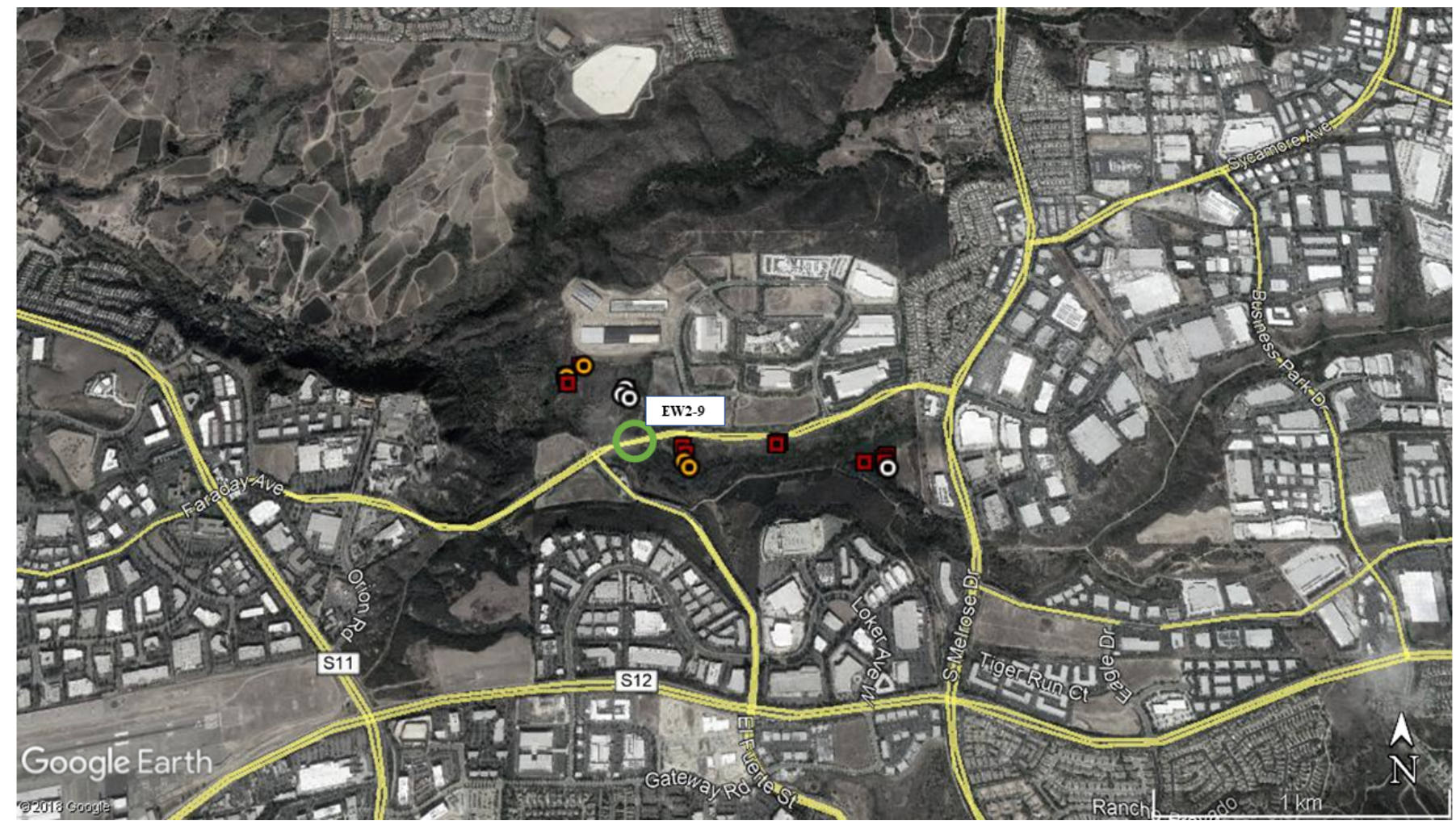

Figure 3. One buck (MDn351 [red squares]) and two does (MDn373 [white circles], MDn403 [yellow circles]) identified moving across Faraday Avenue. Green circle = tunnel, pinch point EW2-9. 


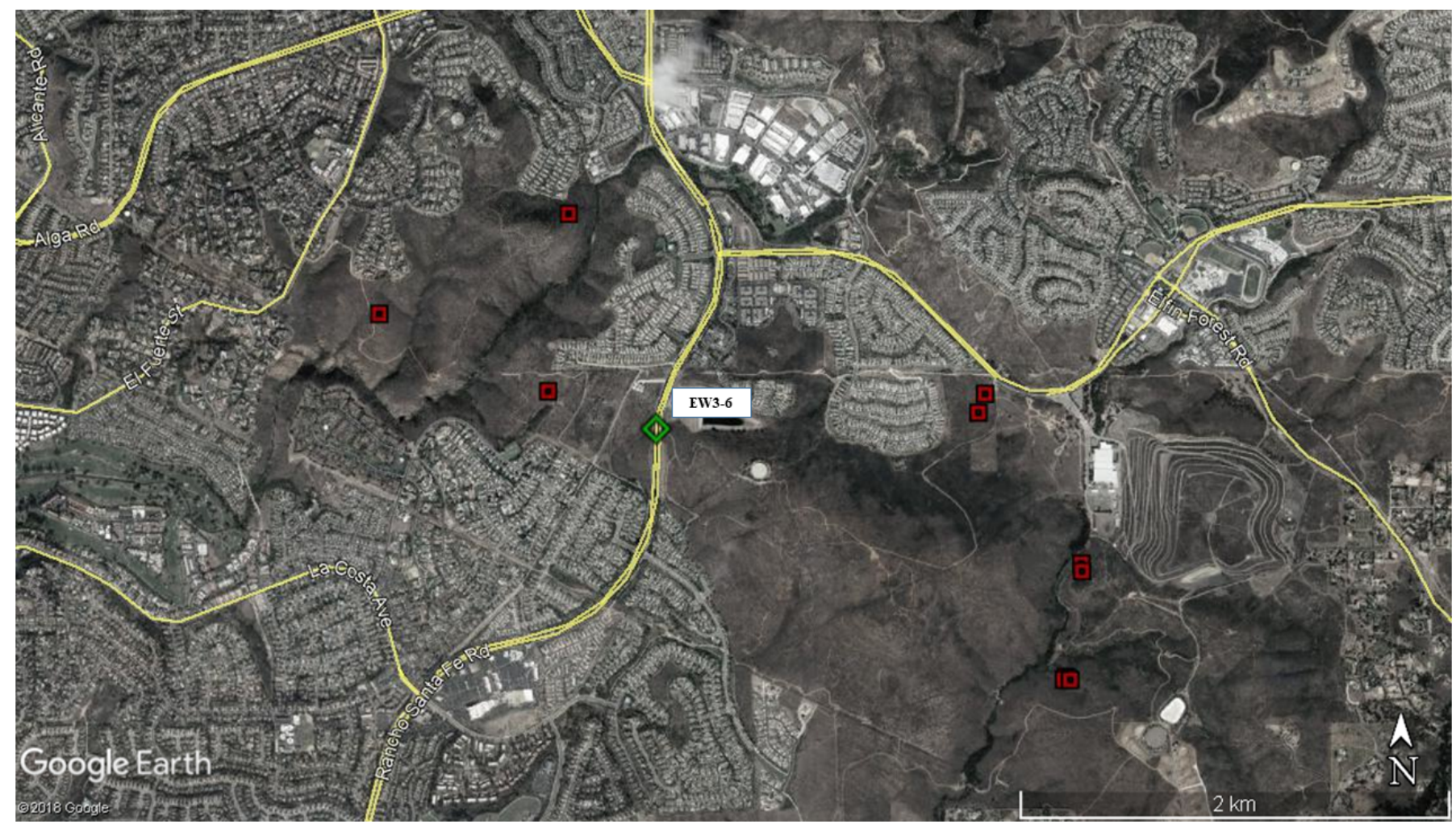

Figure 4. Buck MDn069 with all capture events (red squares). Green diamond = Rancho Santa Fe Road tunnel, pinch point EW3-6.

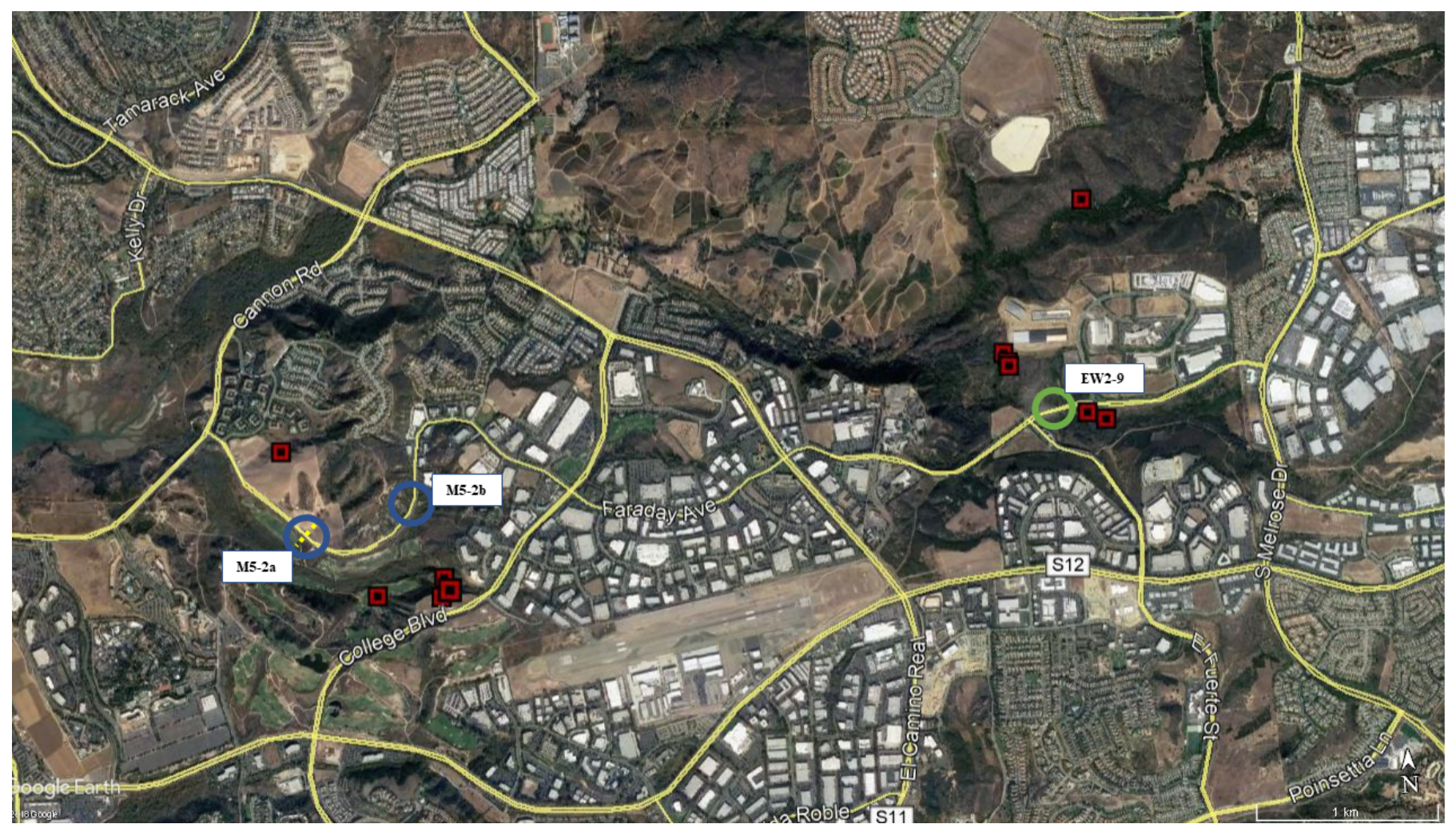

Figure 5. Buck MDn195, with all capture events (red squares). Blue circle = at grade crossing, pinch point M5-2b. Blue circle with yellow dotted line = tunnel, pinch point M5-2a. Green circle = tunnel (see fig. 3). 


\section{Tissue Samples}

Each of 69 tissue-derived genotypes represented a single individual (38 males and 31 females). We identified no recaptures between the scat and tissue-based datasets.

\section{Microsatellite Statistics}

Across the 15 loci in the North County dataset, the $\mathrm{P}_{\text {ID }}$ of $4.9 \times 10^{-11}$ and $\mathrm{P}_{\mathrm{SIB}}$ of $4.6 \times 10^{-5}$ were below the upper limits of 0.01 to 0.0001 recommended for genotypes in natural populations (Waits and others, 2001). Locus B was found to have a high probability of null alleles and was dropped from all pedigree and population structure analyses. The number of alleles (A) for the remaining 14 loci ranged from 2 to 12 per locus and was similar to the regional dataset, with a slightly higher average of 5 (table 4; versus 4.9 in the regional dataset). Average expected heterozygosity $\left(\mathrm{H}_{\mathrm{e}}\right)$ was higher than observed ( 0.612 versus 0.577$)$, which could indicate some inbreeding in the North County region (table 4).

\section{North County Pedigree Analyses}

We used first and second order relatives as another indicator of mule deer movement. Pedigree reconstruction of the North County dataset resulted in 11 full-sibling dyads (8 full-sibling family groups), no parent-offspring dyads, and 9 half-sibling dyads (7 half-sibling family groups; table 5;

Table 4. Microsatellite summary statistics for 14 Southern mule deer loci used for pedigree and population genetic analyses.

[A, number of alleles; $\mathrm{N}$, number of individuals genotyped; $\mathrm{H}_{\mathrm{o}}$, observed heterozygosity; $\mathrm{H}_{\mathrm{e}}$, expected heterozygosity; PIC, polymorphic information content]

\begin{tabular}{lcrccc}
\hline \multicolumn{1}{c}{ Locus } & $\mathbf{A}$ & $\mathbf{N}$ & $\mathbf{H}_{\mathbf{0}}$ & $\mathbf{H}_{\mathbf{e}}$ & $\mathbf{P I C}$ \\
\hline Locus C & 4 & 165 & 0.412 & 0.428 & 0.389 \\
Locus D & 6 & 165 & 0.715 & 0.788 & 0.752 \\
Locus F & 3 & 69 & 0.406 & 0.437 & 0.380 \\
Locus G & 3 & 162 & 0.500 & 0.559 & 0.490 \\
Locus H & 2 & 165 & 0.376 & 0.414 & 0.327 \\
Locus J & 3 & 165 & 0.418 & 0.443 & 0.352 \\
Locus K & 5 & 165 & 0.685 & 0.695 & 0.639 \\
Locus L & 4 & 164 & 0.591 & 0.647 & 0.584 \\
Locus M & 5 & 165 & 0.642 & 0.703 & 0.651 \\
Locus N & 12 & 164 & 0.774 & 0.849 & 0.832 \\
Locus P & 5 & 165 & 0.661 & 0.679 & 0.616 \\
Locus R & 5 & 165 & 0.685 & 0.714 & 0.659 \\
Locus S & 9 & 160 & 0.756 & 0.764 & 0.728 \\
Locus V & 4 & 164 & 0.463 & 0.454 & 0.421 \\
\hline Average & 5.0 & 157 & 0.577 & 0.612 & 0.559 \\
\hline
\end{tabular}

fig. 6). Six full-sibling dyads consisted of relatives located in different sampling sites and across roads of varying size. The five remaining dyads consisted of relatives within the same sampling site. Three individuals, one buck and two does, making up a single full-sibling group (FS4), spanned the north and south sides of Faraday Avenue within the Carlsbad Oaks

North HCA. As in the case of the recaptures, these individuals could be using the tunnel to cross this road (fig. 3; pinchpoint EW2-9, City of Carlsbad, 2015). We identified one pair of female siblings (FS2) spanning the Carlsbad Oaks North and Rancho La Costa HCAs. The $8.5 \mathrm{~km}$ between these does is dissected by multiple roads, including Faraday Avenue, Palomar Airport Road, Ranch Santa Fe Road, Pointsettia Lane, Alga Road, and El Fuerto Street. We found two fullsibling does (FS7) within the San Diego Zoo Safari Park, approximately $2 \mathrm{~km}$ apart, with one found near the Beckman Center and the other in the eastern open space preserve portion of the park, with minor park roads between them. We identified one pair of full-sibling bucks (FS3) about $3 \mathrm{~km}$ apart within the Los Cielos Preserve, on opposite sides of the Del Dios Highway.

We found eight half-sibling pairs (table 5; fig. 6). Two half-sibling pairs (HS1 and HS2) were found within the San Diego Zoo Safari Park. One of these groups was a pair of does found $1.4 \mathrm{~km}$ apart. Four half-sibling family groups were found within the MCBCP, with three of these groups occurring between the Coastal and North collection sites at MCBCP and across two minor roads - Los Pulgas Canyon Road (approximately 13-14 km apart) and Basilone Road (approximately $3 \mathrm{~km}$ apart). Finally, we identified two half-sibling does (HS3) approximately $14 \mathrm{~km}$ apart between Hellhole Canyon (Carter residence) and Pamo Valley. There are four single lane roads between these sites.

\section{Regional San Diego County Population Structure and Effective Population Size}

We did not recapture any individuals from the previously analyzed regional San Diego dataset during this study. However, we found three full-sibling dyads and two halfsibling dyads in which North County dataset individuals were related to individuals collected as part of Bohonak and Mitelberg (2014) and Mitelberg and Vandergast (2016). In the first pair of full siblings, both mule deer were found at the San Diego Zoo Safari Park (6 years and $1.1 \mathrm{~km}$ apart). The second pair consisted of two siblings, both found in Carlsbad, one at Carlsbad Oaks North HCA and the other at Rancho La Costa HCA (5 years and $6.6 \mathrm{~km}$ apart). In the third pair, one sibling was detected in Hellhole Canyon (Carter residence), and its sibling was detected east of SR-67 and south of Foster Truck Trail (3 years and $31.4 \mathrm{~km}$ apart). We found one pair of half siblings between and Rancho La Costa (Choumas-Pappas) and Miramar Golf Course 6 years and $20.6 \mathrm{~km}$ apart. We found a second pair of half siblings between North MCBCP and Boulder Oaks Preserve east of SR-67, 3 years and $69 \mathrm{~km}$ apart. 
Table 5. Family groups of Southern mule deer (full and half siblings with $p \geq 0.80$ ) identified in the north San Diego County 2018-19 dataset, Euclidean distance between siblings, potential roads crossed, and whether crossing occurred across sampling sites.

[Samples in bold appear in more than one dyad. Number in parentheses corresponds to site number assigned in table 1. Abbreviations: $\mathrm{m}$, meter; ff, female female; $\mathrm{mm}$, male male; fm, female male]

\begin{tabular}{|c|c|c|c|c|c|}
\hline $\begin{array}{l}\text { Family } \\
\text { group }\end{array}$ & $\begin{array}{l}\text { Full-sibling } \\
\text { (FS)/Half- } \\
\text { sibling (HS) } \\
\text { Dyad }\end{array}$ & Gender & $\begin{array}{l}\text { Distance } \\
\quad(\mathrm{m})\end{array}$ & Road crossings? & Across sampling sites? \\
\hline FS2 & $\begin{array}{l}\text { MDn098- } \\
\text { MDn403 }\end{array}$ & $\mathrm{ff}$ & 8,458 & $\begin{array}{l}\text { Multiple possible routes and barriers — Faraday } \\
\text { Ave.; Palomar Airport Rd.; Rancho Santa Fe } \\
\text { Rd.; Pointesettia Ln.; Alga Rd.; El Fuerte St. }\end{array}$ & $\begin{array}{l}\text { Carlsbad Oaks North HCA - North Faraday } \\
\text { (15)/ Rancho La Costa HCA - Copper } \\
\text { Creek (23) }\end{array}$ \\
\hline FS3 & $\begin{array}{l}\text { SPn131- } \\
\text { MDn165 }\end{array}$ & $\mathrm{mm}$ & 2,925 & Del Dios Hwy. & $\begin{array}{l}\text { Los Cielos Preserve-Cielos Estates (28)/ } \\
\text { Los Cielos Preserve-Meisha Canyon (29) }\end{array}$ \\
\hline FS4 & $\begin{array}{l}\text { MDn439- } \\
\text { MDn351 }\end{array}$ & fm & 1,399 & Faraday Ave. (tunnel; EW2-9) & $\begin{array}{l}\text { Carlsbad Oaks North HCA - North Faraday } \\
\text { (15)/South Faraday (16) }\end{array}$ \\
\hline FS4 & $\begin{array}{l}\text { SPn438- } \\
\text { MDn351 }\end{array}$ & fm & 1,386 & Faraday Ave. (tunnel; EW2-9) & $\begin{array}{l}\text { Carlsbad Oaks North HCA-North Faraday } \\
\text { (15)/South Faraday (16) }\end{array}$ \\
\hline FS5 & $\begin{array}{l}\text { MDn608- } \\
\text { MDn613 }\end{array}$ & $\mathrm{ff}$ & 47 & No & No \\
\hline FS6 & $\begin{array}{l}\text { SPn462- } \\
\text { SPn468 }\end{array}$ & ff & 47 & No & No \\
\hline FS7 & $\begin{array}{l}\text { SPn580- } \\
\text { SPn588 }\end{array}$ & $\mathrm{ff}$ & 2,142 & Minor roads within San Diego Zoo Safari Park & $\begin{array}{l}\text { San Diego Zoo Safari Park Beckman \& } \\
\text { Tram (6)/San Diego Zoo Safari Park } \\
\text { Open Space (8) }\end{array}$ \\
\hline FS7 & $\begin{array}{l}\text { SPn588- } \\
\text { SPn568 }\end{array}$ & $\mathrm{fm}$ & 20 & No & No \\
\hline FS8 & T652-T683 & $\mathrm{ff}$ & 1,899 & No & No \\
\hline HS4 & T643-T625 & fm & 14,356 & No & Coastal MCBCP (1) - North MCBCP (2) \\
\hline HS5 & Т629-T664 & ff & 13,999 & Las Pulgas Canyon Rd. & No \\
\hline HS5 & T664-T644 & $\mathrm{fm}$ & 13,453 & Las Pulgas Canyon Rd. & Coastal MCBCP (1) - North MCBCP (2) \\
\hline HS6 & T654-T657 & ff & 2,973 & Basilone Rd. & No \\
\hline HS7 & T668-T667 & $\mathrm{fm}$ & 12,897 & No & No \\
\hline HS7 & T668-T689 & $\mathrm{fm}$ & 11,661 & No & Coastal MCBCP (1) - North MCBCP (2) \\
\hline
\end{tabular}




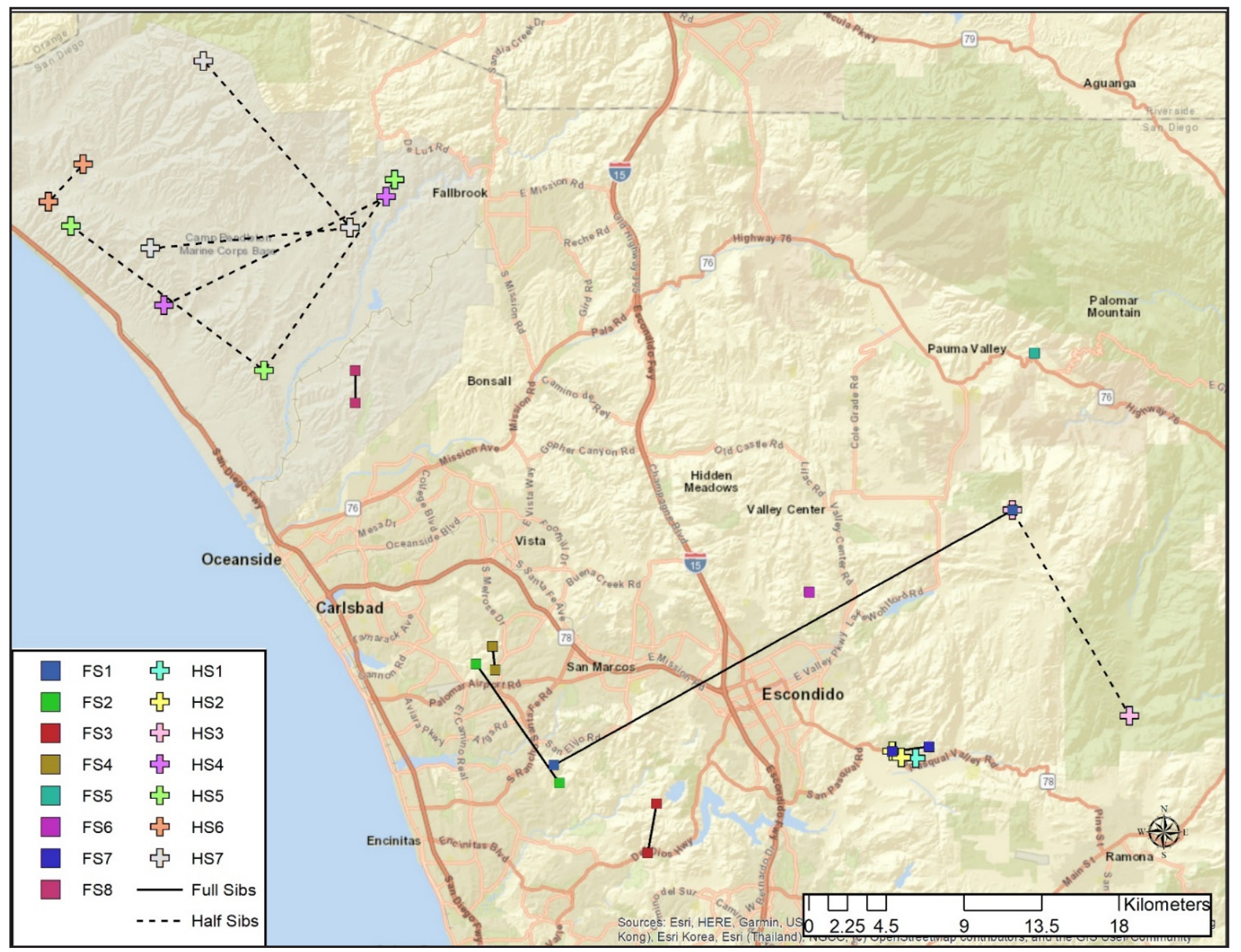

Figure 6. Full- and half-sibling Southern mule deer groups $(P \geq 0.80)$ identified by COLONY in the north San Diego County focus area.

To reduce bias associated with sampling family groups in population clustering analyses, we removed 36 individuals from the regional dataset that appeared in one or more fullsibling dyads. STRUCTURE analyses with and without prior location information indicated $\mathrm{k}=2$ as the most likely number of genetic clusters in the regional dataset, regardless of which method we used to evaluate k (Evanno's $\Delta \mathrm{K}$ or Pritchard's $\ln (\operatorname{Pr}(\mathrm{X} \mid \mathrm{K})$; figs. 7, 8). Across San Diego County, the first cluster (from here on referred to as "Coastal") consists of sites south of SR-78 and west of I-15, including sites in the following six putative geographic populations in San Diego, La Mesa, and Carlsbad (SW-NoC, West, MT-TR-MirDEG, MirNW, CC-MirEM, and Pq-PC, as identified in fig. 1). The second genetic cluster (from here on referred to as "Inland/ Mountain") is composed of sites mostly east of I-15, as well as northern sites north of SR-76 and west of I-15 and includes sites in the following five putative geographic populations: BC-SC, East, NE-NoC, NW-NoC, and SE. In north San Diego County, the Coastal cluster is composed of individuals from
Carlsbad and western portions of Escondido, and the Inland/ Mountain cluster is composed of mule deer from Fallbrook, Valley Center, Pauma Valley, and Lake Sutherland. The Inland/Mountain cluster also contains all mule deer sampled on MCBCP. Mule deer from the eastern portions of Escondido (Daley Ranch Preserve and San Diego Zoo Safari Park) derive approximately 50 percent of their genetic background from each of these clusters.

After cross-validating the DAPC, 40 PCs achieved the lowest root mean square error with a value of $40(0.4471375)$, resulting in an assignment rate of 0.56 . We detected some separation along axis 1 between most Coastal putative geographic populations (that is, West, MT-TR-MirDEG, MirNW, CC-Mir, and Pq-PC) and the remaining sampling sites (fig. 9), although Coastal and Inland/Mountain clusters overlapped (fig. 10). These patterns were similar to the results from the STRUCTURE analyses, with individuals assigning to both clusters at intermediate sampling areas. 


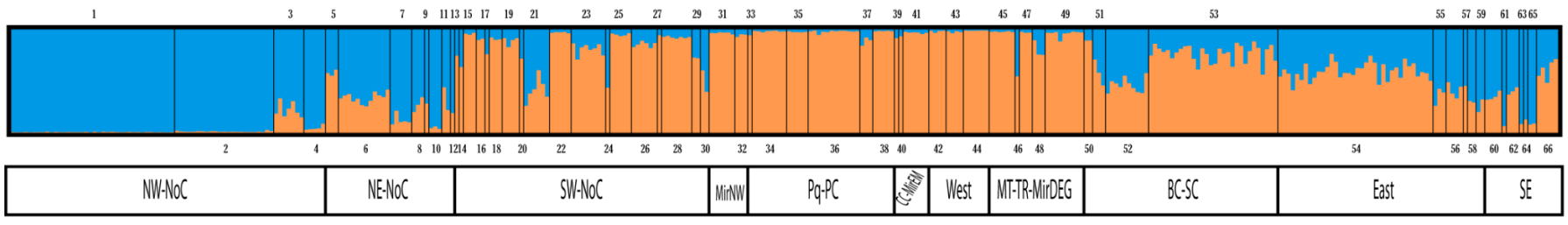

Figure 7. STRUCTURE plot for the regional San Diego County dataset (2005-19). Each bar in the plot represents one of 359 unique unrelated Southern mule deer included in the analysis with the colors representing the proportion of each individual's genetic background assigned to one of two clusters proposed by STRUCTURE. Numbers represent sites, and rectangles represent putative populations as detailed in table 1.

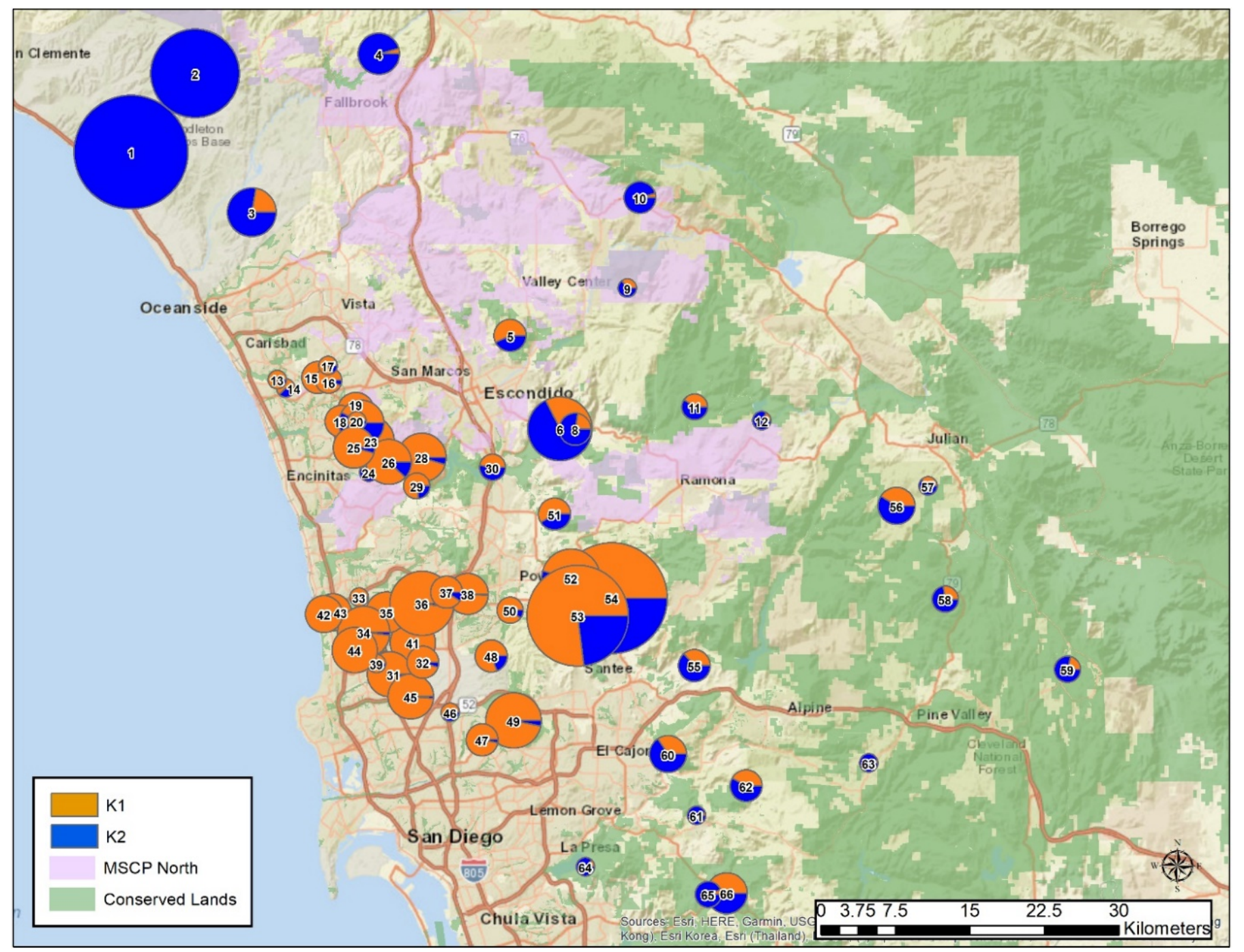

Figure 8. Sites sampled in San Diego County between 2005 and 2019, with each pie chart representing the proportion of the site's genetic background assigned to each of two genetic clusters, as identified by STRUCTURE (a priori site information included in analysis). Pie charts are proportional to the number of Southern mule deer fingerprinted at the site, with the smallest pie consisting of one individual. For accuracy, pies are placed at the center of each sampling site, resulting in some overlap; a map with finer detail of the central and southern areas is provided in appendix 1 (appendix fig. 1.2). 


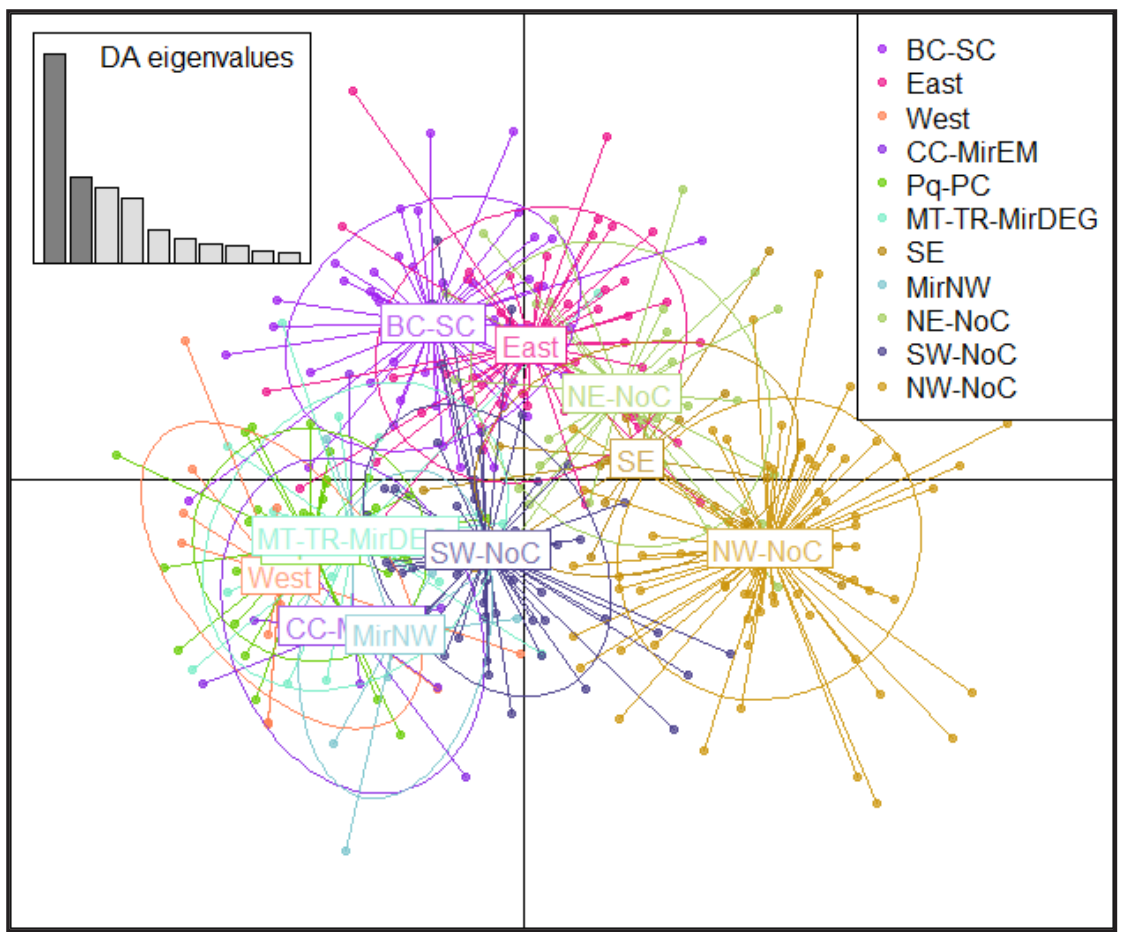

Figure 9. Sampled Southern mule deer by discriminant analysis (DA) eigenvalues axes 1 ( $x$-axis) and 2 ( $y$-axis). Individuals are colored by their population assignments. Color scheme corresponds to fig. 1 .

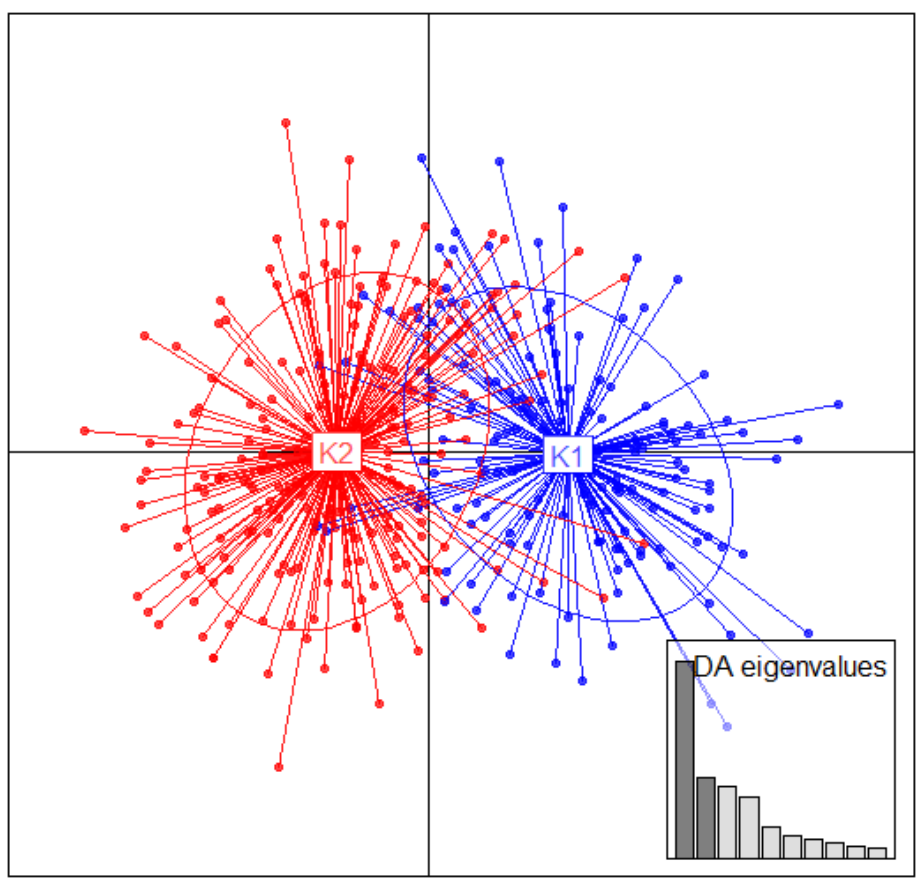

Figure 10. Sampled Southern mule deer by discriminant analysis (DA) 1 (x-axis) and DA 2 (y-axis). Individuals are colored by their STRUCTURE genetic cluster assignments, where individuals are assigned to one of two genetic clusters, $\mathrm{K} 1$ or K2, from which it derives more than 50 percent of its genetic background. 
Fifty-one of fifty-five pairwise $\mathrm{F}_{\mathrm{ST}}$ values were significant $(\mathrm{p} \leq 0.00091)$ after Bonferroni correction (table 6). Significant $\mathrm{F}_{\mathrm{ST}}$ values varied from 0.024 , between $\mathrm{BC}-\mathrm{SC}$ and East (both sites east of I-15), to 0.146 , between NW-NoC and CC-MirEM. Consistent with the STRUCTURE results, sites within the same cluster have lower $\mathrm{F}_{\mathrm{ST}}$ values than sites between clusters.
The $\mathrm{N}_{\mathrm{e}}$ estimate for the Coastal cluster (64.8; 51.1-83.9) is approximately two-thirds that of the Inland/Mountain cluster $(100 ; 81.5-125.3$; table 7$)$. The average number of alleles is also higher in the Inland/Mountain cluster than in the Coastal cluster (4.3 versus 3.5; table 7), suggesting the latter is less diverse.

Table 6. Pairwise $\mathrm{F}_{\mathrm{ST}}$ (genetic differentiation) tests performed in StrataG.

[Numbers in bold are significant at 0.05 after Bonferroni correction for 55 tests.]

\begin{tabular}{|c|c|c|c|c|c|c|c|c|c|c|}
\hline & NW-NoC & NE-NoC & SW-NoC & MirNW & $\mathrm{Pq}-\mathrm{PC}$ & CC-MirEM & West & $\begin{array}{l}\text { MT-TR- } \\
\text { MirDEG }\end{array}$ & BC-SC & East \\
\hline NE-NoC & 0.037 & & & & & & & & & \\
\hline MirNW & 0.108 & 0.081 & 0.078 & & & & & & & \\
\hline Pq-PC & 0.116 & 0.100 & 0.080 & 0.038 & & & & & & \\
\hline MT-TR-MirDEG & 0.096 & 0.092 & 0.050 & 0.071 & 0.032 & 0.072 & 0.030 & & & \\
\hline BC-SC & 0.063 & 0.059 & 0.048 & 0.098 & 0.057 & 0.106 & 0.093 & 0.040 & & \\
\hline East & 0.053 & 0.061 & 0.040 & 0.092 & 0.085 & 0.113 & 0.110 & 0.059 & 0.024 & \\
\hline SE & 0.029 & 0.027 & 0.085 & 0.063 & 0.078 & 0.112 & 0.131 & 0.080 & 0.049 & 0.049 \\
\hline
\end{tabular}

Table 7. $\mathrm{N}_{\mathrm{e}}$ (effective population size), as estimated in $\mathrm{N}_{\mathrm{e}}$ Estimator, using LD, at 0.05 frequency for the lowest allele.

\begin{tabular}{ccccc}
\hline $\begin{array}{c}\text { Genetic } \\
\text { cluster }\end{array}$ & $\begin{array}{c}\text { Putative } \\
\text { geographic } \\
\text { population }\end{array}$ & $\begin{array}{c}\text { Sample } \\
\text { size }\end{array}$ & Alleles & $\begin{array}{c}\mathbf{N}_{\mathbf{e}} \text { (minimum, } \\
\text { maximum) }\end{array}$ \\
\hline $\begin{array}{l}\text { Inland/Mountain (north of } \\
\text { I-76, east of I-15) }\end{array}$ & 213 & 4.3 & $100.2(81.5,125.3)$ \\
\hline NW-NoC & 73 & 4.6 & $178.2(93.2,796)$ \\
NE-NoC & 30 & 4.4 & $17.8(12.6,26.4)$ \\
BC-SC & 45 & 3.9 & $77.3(39.5,333.4)$ \\
East & 48 & 4.4 & $53.9(35,98.2)$ \\
SE & 17 & 4.1 & $39.3(16$, infinite) \\
\hline Coastal (coastal, south of & 146 & 3.5 & $64.8(51.1,83.9)$ \\
I-78; west of I-15) & & & \\
\hline SW-NoC & 59 & 4.0 & $45.1(31.7,69.4)$ \\
West & 14 & 3.1 & $17.5(7.2,127.5)$ \\
MT-TR-MirDEG & 22 & 3.9 & $21(11.9,47.9)$ \\
MirNW & 9 & 3.2 & $11.9(3.1,21917.2)$ \\
Pq-PC & 34 & 3.9 & $180.1(54.6$, infinite) \\
CC-MirEM & 8 & 2.8 & $19.3(3$, infinite) \\
\hline
\end{tabular}




\section{Discussion}

\section{Mule Deer Movement and Connectivity in North County}

Our primary objective was to assess mule deer movement and gene flow across North County. Scat recaptures and locations of first-order relatives indicate mule deer movement is limited, occurring for the most part within the putative geographic populations rather than between them. Additionally, we found that the mule deer fall into one of two regional genetic clusters identified in the regional San Diego County analyses (that is, Coastal and Inland/Mountain). Below, we discuss connectivity within and between each cluster.

\section{Connectivity Within the Coastal Genetic Cluster in North County}

Several lines of evidence suggest movement and gene flow within and between urban preserves in North County. First, regional population clustering analyses show that mule deer in this region (putative geographic population SW-NoC) derive most of their genetic background from the Coastal genetic cluster.

Second, we identified multiple recaptures between preserves. Two bucks were identified at multiple sites within and among preserves, traveling up to $4.6 \mathrm{~km}$ in less than 3 weeks, potentially using tunnels and crossing roads directly at grade. Within a period of two weeks, buck MDn069 was identified in the Copper Creek, Ridgeline, and Winston sites of Rancho La Costa HCA (table 3; fig. 4). There is a long and dark underpass in this area, but use by mule deer has not been observed (Markus Spiegelberg, written commun., 2019; City of Carlsbad, 2015); therefore, we suspect this individual crossed Rancho Santa Fe Road at grade (pinch point EW36; City of Carlsbad, 2015). Also, within a period of 25 days, buck MDn195 was identified at multiple sites as far as $4.6 \mathrm{~km}$ apart moving between Veterans Park, Crossings Golf Course, north and south of Faraday Avenue, and the Dawson Los Monos Canyon Reserve (table 3; fig. 5). Although we cannot trace this mule deer's exact route, this individual is likely moving along Agua Hedionda Creek, through agricultural fields and riparian areas of Agua Hedionda Lagoon and is likely using underpasses and(or) bridges at El Camino Real Road and Cannon Road; it may have crossed Faraday Avenue at grade (pinch point M5-2b; City of Carlsbad, 2015), as the undercrossing (pinch point M5-2a; City of Carlsbad, 2015) is locked at night. A recent mule deer hit on Faraday Avenue near
Crossing Golf Course and Veterans Park indicates that mule deer are in fact attempting to cross Faraday Avenue here at grade (Markus Spiegelberg, written commun., 2019).

Third, pedigree analyses identified full- and halfsibling relatives at different preserves and(or) sites within the preserves in the short- ( $\sim$ scat collected up to 1 month apart) and long-term ( $\sim$ scat collected 5 or more years apart). Preserves in western Escondido share a pair of full siblings between the two sites in the Los Cielos Preserve located across Del Dios Highway, suggesting recent movement between these sites.

\section{Connectivity Within the Inland/Mountain Genetic Cluster in North County}

Evidence for relatively short-term gene flow within the Inland/Mountain genetic cluster includes (1) half siblings between the North and Coastal sites at MCBCP and (2) a half-sibling pair between Hellhole Canyon (Carter residence) and Pamo Valley. A long-term connection is supported by population clustering results, which show that individuals collected at sites in the NW-NoC and NE-NoC putative geographic populations derive a large proportion of their genetic background from the same genetic cluster. $\mathrm{F}_{\mathrm{ST}}$ values between NW-NoC and NE-NoC are low (0.037) and are almost half that of NW-NoC and SW-NoC (0.064), suggesting that there has been more gene flow between the former putative geographic populations across I-15 than between the latter across SR-78.

\section{Connectivity Between Genetic Clusters in North County}

We found no recaptures or first order relatives and identified only one half-sibling pair between Rancho La Costa and Hellhole Canyon in Valley Center (although this pair had low support just above our cut-off value of $\mathrm{p} \geq 0.80$ ). However, populations clustering results indicate that gene flow has occurred between the two genetic clusters in North County. Connectivity is likely being maintained under the I-15 overpass, via Lake Hodges as well as Daley Ranch Preserve and San Diego Zoo Safari Park, at sites where individuals derive $\sim 50$ percent of their genetic background from each genetic cluster (fig. 7). Finally, the eastern MCBCP site contains individuals with a shared genetic background between the two clusters (fig. 7), suggesting that mule deer may have been able to move more freely through the San Marcos Mountains in the recent past. 


\section{Regional San Diego County Mule Deer Connectivity, Diversity, and Effective Population Size}

Our secondary goal was to assess regional mule deer connectivity across all of San Diego County. We found evidence for two regional clusters in San Diego County, corroborating results from previous regional (Bohonak and Mitelberg, 2014; Mitelberg and Vandergast, 2016) and statewide landscape genetic studies (Pease and others, 2009). Sites in the SW-NoC putative geographic population (Carlsbad and west Escondido) and coastal sites south of I-56 and west of I-15 (including sites in MirNW, Pq-PC, CC-MirEM, West, Mt-TR-MirDEG) belong to the same genetic cluster. Sites in the NW-NoC and NE-NoC belong to the same genetic cluster as sites east of I-15 (including sites in BC-SC and East), as well as sites in the southeast part of the county (SE). This cluster likely extends northward through the Santa Ana Mountains based on overlap with previously published studies that include more northern collection locations (Pease and others, 2009; Fraser and others, 2019).

Interestingly, sites that are far apart geographically, but within the Inland/Mountain genetic cluster, such as those in the NW-NoC putative geographic population and sites in $\mathrm{SE}$ and East, have small and significant $\mathrm{F}_{\mathrm{ST}}$ values of 0.029 and 0.053 (fig. 1; table 6). In contrast, sites that are closer together geographically, but are in different genetic clusters, such as those in the West and NW-NoC, or West and $\mathrm{SE}$, have larger, significant $\mathrm{F}_{\mathrm{ST}}$ values of 0.145 and 0.131 , respectively. This could indicate an effect of urban barriers inhibiting connectivity among some geographic populations or behavioral differences in movement patterns that are related to genetic differences.

In a study of mule deer throughout California, Pease and others (2009) described two major genetic clusters for mule deer in southern California. The San Diego cluster consisted of samples from San Diego County, west of the Peninsular Range in the coastal plain. The geographically larger southern cluster included individuals collected east of San Diego in Imperial County, MCBCP, and northward into the southern Sierra Nevada Mountains and Coastal Range (Pease and others 2009, fig. 1). The Pease and others (2009) genetic clusters also roughly corresponded to subspecies' range limits. The San Diego cluster corresponds to the Southern mule deer (Odocoileus hemionus fuliginatus), whereas the southern cluster overlaps most of the California mule deer (Odocoileus hemionus californicus) subspecies range. These clusters correspond spatially to the two San Diego County clusters recovered in our study, but we identify several zones of admixture, possibly as a result of finer-scale sampling efforts. If the Coastal cluster is equivalent to the Southern mule deer subspecies, then the subspecies appears to be restricted to a smaller portion of San Diego County than previously described, mainly residing in coastal San Diego, west of I-15. Further sampling in eastern San Diego County might resolve the eastern contact zones. The genetic diversity and effective population size of the Coastal cluster are lower than in the Inland/Mountain cluster, and $\mathrm{N}_{\mathrm{e}}$ for the Coastal cluster is below the recommended threshold of 100 to avoid inbreeding depression (Frankham and others, 2014). This may be because the Inland/Mountain genetic cluster encompasses a much larger area and number of individuals than the Coastal cluster with fewer restrictions to movement. Pease and others (2009) also reported that genetic diversity for the San Diego County Southern mule deer was lower than other subspecies of mule deer in California. Finally, the Southern mule deer subspecies range also extends into Baja California, Mexico, although we have no samples from south of the United States/Mexico border to which to compare diversity and gene flow estimates.

Comparing among North County and other sampling areas in San Diego, levels of genetic diversity within North County $\left(\mathrm{A}=5.0\right.$ and $\left.\mathrm{H}_{\mathrm{e}}=0.61\right)$ are slightly lower than all of San Diego County samples combined $\left(A=6.0\right.$ and $\left.\mathrm{H}_{\mathrm{e}}=0.63\right)$. Likewise, genetic diversity appears slightly higher across San Diego geographic populations than reported in other regions of southern California, using the same microsatellite markers. Fraser and others (2019) examined geographic populations of mule deer in Orange and Los Angeles Counties and reported $\mathrm{H}_{\mathrm{e}}$ ranging from 0.52 in Chino Hills to 0.59 in the Verdugo Mountains and Hollywood Hills (all in Los Angeles County) and $\mathrm{N}_{\mathrm{e}}$ ranging from 16.6 in the San Joaquin Hills (Orange County) to over 236 in the Santa Ana Mountains.

\section{Conclusions and Future Work}

We have shown that short-term genetic monitoring in relatively small regions of interest, and where mule deer presence has been documented, can provide useful information on mule deer movement. Until now, no region has been sampled as intensively as the city of Carlsbad preserves, which may, in part, explain why previous DNA fingerprinting efforts resulted in low recapture rates and distances (no more than $1.56 \mathrm{~km}$ apart; Valero, 2004; Bohonak and Mitelberg, 2014; Mitelberg and Vandergast, 2016). In the study presented here, we were able to capture mule deer movements of up to $4.6 \mathrm{~km}$ within 3 weeks. Additionally, our short-term intensive genetic monitoring indicates that mule deer successfully use infrastructure, such as tunnels and culverts as well as cross roads at grade. At-grade crossings can put drivers and mule deer at risk. Providing additional deer-appropriate undercrossings in areas where at-grade crossings are apparent could help avoid accidents and maintain gene flow. This type of intensive, short-term genetic monitoring effort could be implemented in other urban areas in the county where mule deer movement throughout the landscape is a concern. 
Obtaining fresh scat samples in less urban areas, and where mule deer are presumably less concentrated, has proven more challenging. Therefore, evidence for connectivity from recaptures and first-order relatives may be limited owing to small sample sizes and dispersion of sampling sites. Suggestions for improving sampling success in relatively large areas of interest include (1) continuing scat collections over time and storing scat for later analysis (also suggested in Bohonak and Mitelberg, 2014), (2) notifying and encouraging the public to track mule deer sightings through iNaturalist or other apps, and (3) enlisting the help of preserve managers for opportunistic scat collections.

Finally, there are other research efforts employing the same genetic markers to study mule deer populations in San Diego County and other parts of southern California (Fraser and others, 2019). Efforts to combine these datasets could provide a more comprehensive picture of subspecies ranges and connectivity among local geographic populations of mule deer. Such efforts could assist in monitoring mule deer for long-term persistence in the region.

\section{References Cited}

Alberto, F., 2009, MsatAllele_1.0-An R package to visualize the binning of microsatellite alleles: Journal of Heredity, v. 100, no. 3, p. 394-397, https://doi.org/10.1093/jhered/esn110.

Archer, F.I., Adams, P.E., and Schneiders, B.B., 2017, STRATAG-An R package for manipulating, summarizing and analyzing population genetic data: Molecular Ecology Resources, v. 17, no. 1, p. 5-11, https://doi.org/10.1111/1755-0998.12559.

Bohonak, A.J., and Mitelberg, A., 2014, Social structure and genetic connectivity in the southern Mule Deer-Implications for management: Prepared for California Department of Fish and Wildlife Service in fulfillment of Local Assistance Grant No. P1182117, https://pdfs.semanticscholar.org/8da6/3d4bcb9d2f3ad409df 6a068538de5722a5f3.pdf.

Bonin, A., Bellemain, E., Bronken Eidesen, P., Pompanon, F., Brochmann, C., and Taberlet, P., 2004, How to track and assess genotyping errors in population genetics studies: Molecular Ecology, v. 13, no. 11, p. 3261-3273, https://doi.org/10.1111/j.1365-294X.2004.02346.x.
City of Carlsbad, 2015, City of Carlsbad wildlife movement analysis final report: Center for Natural Lands Management (CNLM), and Environmental Science Associates (ESA), Prepared for California Department of Fish and Wildlife Service in fulfillment of Local Assistance Grant No. P1282107, accessed April 2019 at https://sdmmp.com/upload/SDMMP_Repository/0/ cv72xhqwsnrkfb8yzmj940p56d31 gt.pdf.

City of San Diego, 2002, Multiple species conservation program-MSCP 2002 Annual Report: County of San Diego, Calif., accessed March 2019 at https://www.sandiegocounty.gov/content/dam/sdc/ parks/RMD/RMPs\%20and\%20Trails/2002_MSCP_ AnnualReport.pdf.

Colby, J., 2008, Comparison of VHF and GPS data from radio-collared female mule deer-location error, home range attributes, and habitat selection: Master's thesis, Calfiornia State University San Marcos, San Marcos, Calif., 79 p., http://csusm-dspace.calstate.edu/bitstream/ handle/10211.3/10211.8 331/ColbyJanene_Spring2008. pdf? sequence $=4$.

Do, C., Waples, R.S., Peel, D., Macbeth, G.M., Tillett, B.J., and Ovenden, J.R., 2014, NeEstimator V2-

Re-implementation of software for the estimation of contemporary effective population size $\left(\mathrm{N}_{\mathrm{e}}\right)$ from genetic data: Molecular Ecology Resources, v. 14, no. 1, p. 209214, https://doi.org/10.1111/1755-0998.12157.

Falush, D., Stephens, M., and Pritchard, J.K., 2003, Inference of population structure using multilocus genotype data-Linked loci and correlated allele frequencies: Genetics, v. 164, no. 4, p. 1567-1587, https://www.ncbi.nlm.nih.gov/pmc/articles/PMC1462648/.

Frankham, R., Bradshaw, C.J.A., and Brook, B.W., 2014, Genetics in conservation managementRevised recommendations for the 50/500 rules, Red List criteria and population viability analyses: Biological Conservation, v. 170, p. 56-63, https://doi.org/10.1016/j.biocon.2013.12.036.

Fraser, D.L., Ironside, K., Wayne, R.K., and Boydston, E.E., 2019, Connectivity of mule deer (Odocoileus hemionus) populations in a highly fragmented urban landscape: Landscape Ecology, v. 34, no. 5, p. 1097-1115, https://doi.org/10.1007/s10980-019-00824-9. 
Hayden, S.K., 2002, The effects of habitat fragmentation on large mammals in a San Diego county regional corridor: Master's thesis, San Diego State University, San Diego, Calif., 93 p.

Jombart, T., 2008, adegenet-A R package for the multivariate analysis of genetic markers: Bioinformatics (Oxford, England), v. 24, no. 11, p. 1403-1405, https://doi.org/10.1093/bioinformatics/btn129.

Jombart, T., Devillard, S., and Balloux, F., 2010, Discriminant analysis of principal components-A new method for the analysis of genetically structured populations: BMC Genetics, v. 11, no. 94, p. 94-108, https://doi.org/10.1186/1471-2156-11-94.

Jones, O.R., and Wang, J., 2010, COLONY-A program for parentage and sibship inference from multilocus genotype data: Molecular Ecology Resources, v. 10, no. 3, p. 551555, https://doi.org/10.1111/j.1755-0998.2009.02787.x.

Kalinowski, S.T., Taper, M.L., and Marshall, T.C., 2007, Revising how the computer program CERVUS accommodates genotyping error increases success in paternity assignment: Molecular Ecology, v. 16, no. 5, p. 1099-1106, https://doi.org/10.1111/j.1365-294X.2007.03089.x.

Kopelman, N.M., Mayzel, J., Jakobsson, M., Rosenberg, N.A., and Mayrose, I., 2015, Clumpak-A program for identifying clustering modes and packaging population structure inferences across $K$ : Molecular Ecology Resources, v. 15, no. 5, p. 1179-1191, https://doi.org/10.1111/1755-0998.12387.

Markovchick-Nicholls, L., Regan, H.M., Deutschman, D.H., Widyanata, A., Martin, B., Noreke, L., and Ann Hunt, T., 2008, Relationships between human disturbance and wildlife land use in urban habitat fragments: Conservation Biology, v. 22, no. 1, p. 99-109, https://doi.org/10.1111/j.1523-1739.2007.00846.x.

Miller, C.R., Joyce, P., and Waits, L.P., 2002, Assessing allelic dropout and genotype reliability using maximum likelihood: Genetics, v. 160, no. 1, p. 357-366, https://www.ncbi.nlm.nih.gov/pmc/articles/PMC1461941/.

Mitelberg, A., 2010, Social structure and genetic connectivity in the San Diego Southern mule deer: Master's thesis, San Diego State University, San Diego, Calif, 76 p.

Mitelberg, A., and Vandergast, A.G., 2016, Non-invasive genetic sampling of southern Mule Deer (Odocoileus hemionus fuliginatus) reveals limited movement across California State Route 67 in San Diego County: Western Wildlife, v. 3, p. 8-18, http://www.tws-west.org/ westernwildlife/vol3/Mitelberg_and_Vandergast_ WW_2016.pdf.
Pease, K.M., Freedman, A.H., Pollinger, J.P., McCormack, J.E., Buermann, W., Rodzen, J., Banks, J., Meredith, E., Bleich, V.C., Schaefer, R.J., Jones, K., and Wayne, R.K., 2009, Landscape genetics of California mule deer (Odocoileus hemionus) - The roles of ecological and historical factors in generating differentiation: Molecular Ecology, v. 18, no. 9, p. 1848-1862, https://doi.org/10.1111/j.1365-294X.2009.04112.x.

Pritchard, J.K., Stephens, M., and Donnelly, P., 2000, Inference of population structure using multilocus genotype data: Genetics, v. 155, no. 2, p. 945-959, https://www.ncbi.nlm.nih.gov/pmc/articles/PMC1461096/.

R Core Development Team, 2011, R-A language and environment for statistical computing: R Foundation for Statistical Computing, Vienna, Austria, available at https://www.R-project.org/.

Rodríguez-Ramilo, S.T., and Wang, J., 2012, The effect of close relatives on unsupervised Bayesian clustering algorithms in population genetic structure analysis: Molecular Ecology Resources, v. 12, no. 5, p. 873-884. https://doi.org/10.1111/j.1755-0998.2012.03156.x.

San Diego Association of Governments, 2003, Final multiple habitat conservation program biological monitoring and management plan - Volume III: San Diego Association of Government web page, accessed April 2019 at https:/www.sandag.org/programs/environment/habitat preservation/mhep_vol3.pdf.

San Diego Management and Monitoring Program, 2011, Connectivity monitoring strategic plan for the San Diego Preserve System, Prepared for the San Diego Environmental Mitigation Program Working Group.

Schwartz, M.K., Luikart, G., and Waples, R.S., 2007, Genetic monitoring as a promising tool for conservation and management: Trends in Ecology \& Evolution, v. 22, no. 1, p. 25-33, https://doi.org/10.1016/j.tree.2006.08.009.

Valero, S.J., 2004, Estimates of genetic variation, gene flow and dispersal of the Southern mule deer (Odocoileus hemionus hemionus) using a non-invasive method: Master's thesis, San Diego State University, 68 p.

Valière, N., 2002, GIMLET-A computer program for analysing genetic individual identification data: Molecular Ecology Resources, v. 2, no. 3, p. 377-379, https://doi.org/10.1046/j.1471-8286.2002.00228.x-i2.

van Etten, J., 2017, R Package gdistance-Distances and routes on geographical grids: Journal of Statistical Software, v. 76, no. 13, p. 1548-7660, https://doi.org/10.18637/jss.v076.i13. 
Waits, L.P., Luikart, G., and Taberlet, P., 2001, Estimating the probability of identity among genotypes in natural populations - Cautions and guidelines: Molecular Ecology, v. 10, no. 1, p. 249-256, https://doi.org/10.1046/j.1365-294X.2001.01185.x.

Wang, J., 2004, Sibship reconstruction from genetic data with typing errors: Genetics, v. 166, no. 4, p. 1963-1979, https://doi.org/10.1534/genetics.166.4.1963.

Wang, J., and Santure, A.W., 2009, Parentage and sibship inference from multilocus genotype data under polygamy: Genetics, v. 181, no. 4, p. 1579-1594, https://doi.org/10.1534/genetics.108.100214.
Warner, P.A., Willis, B.L., and van Oppen, M.J.H., 2016, Sperm dispersal distances estimated by parentage analysis in a brooding scleractinian coral: Molecular Ecology, v. 25, no. 6, p. 1398-1415, https://doi.org/10.1111/mec.13553.

Wright, S., 1965, The interpretation of population structure by F-statistics with special regard to systems of mating: Evolution; International Journal of Organic Evolution, v. 19, no. 3, p. 395-420, https://doi.org/10.1111/j.1558-5646.1965.tb01731.x. 


\section{Appendix 1}

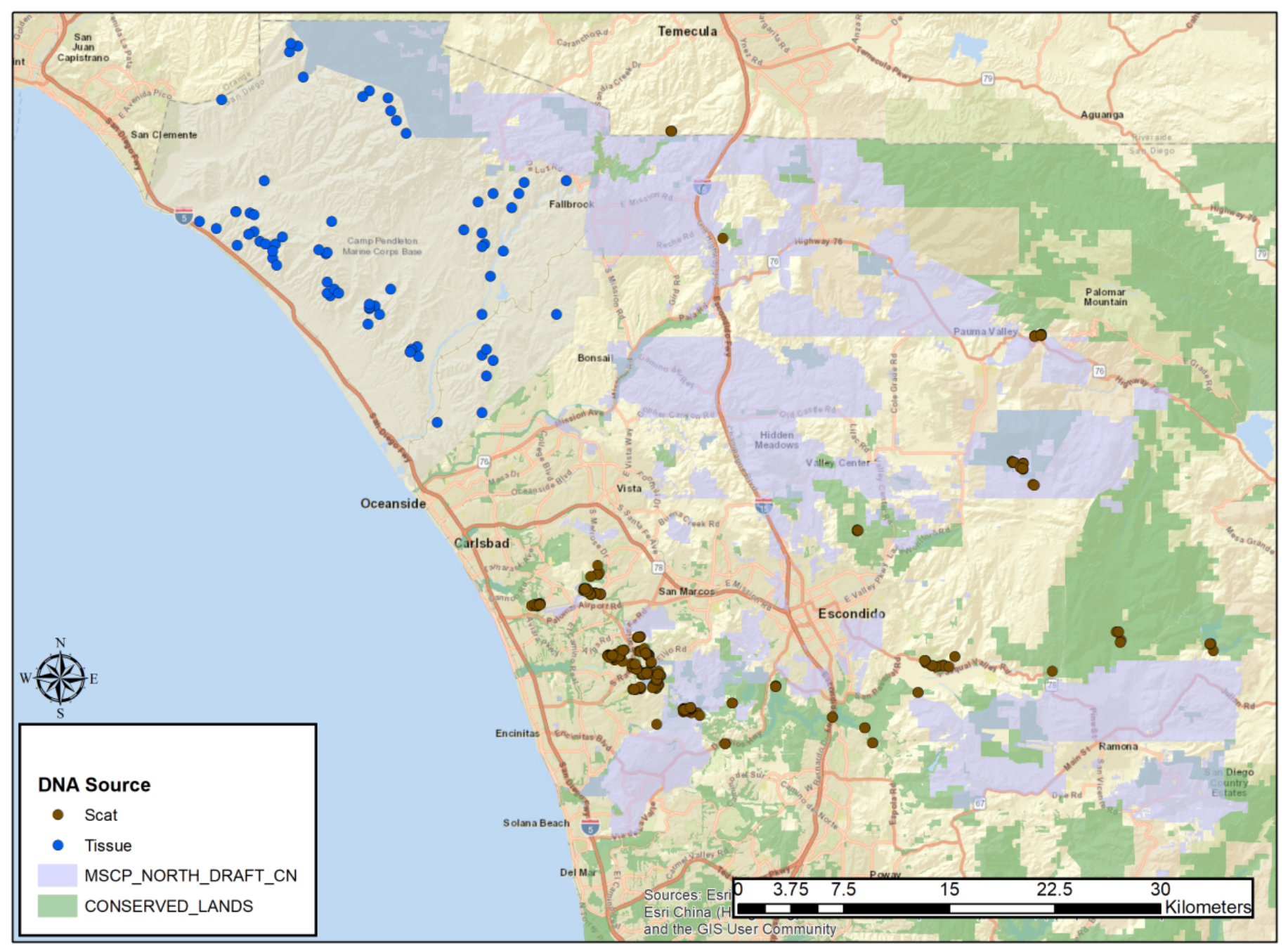

Figure 1.1. Southern mule deer tissue and scat samples obtained in 2018-19. 


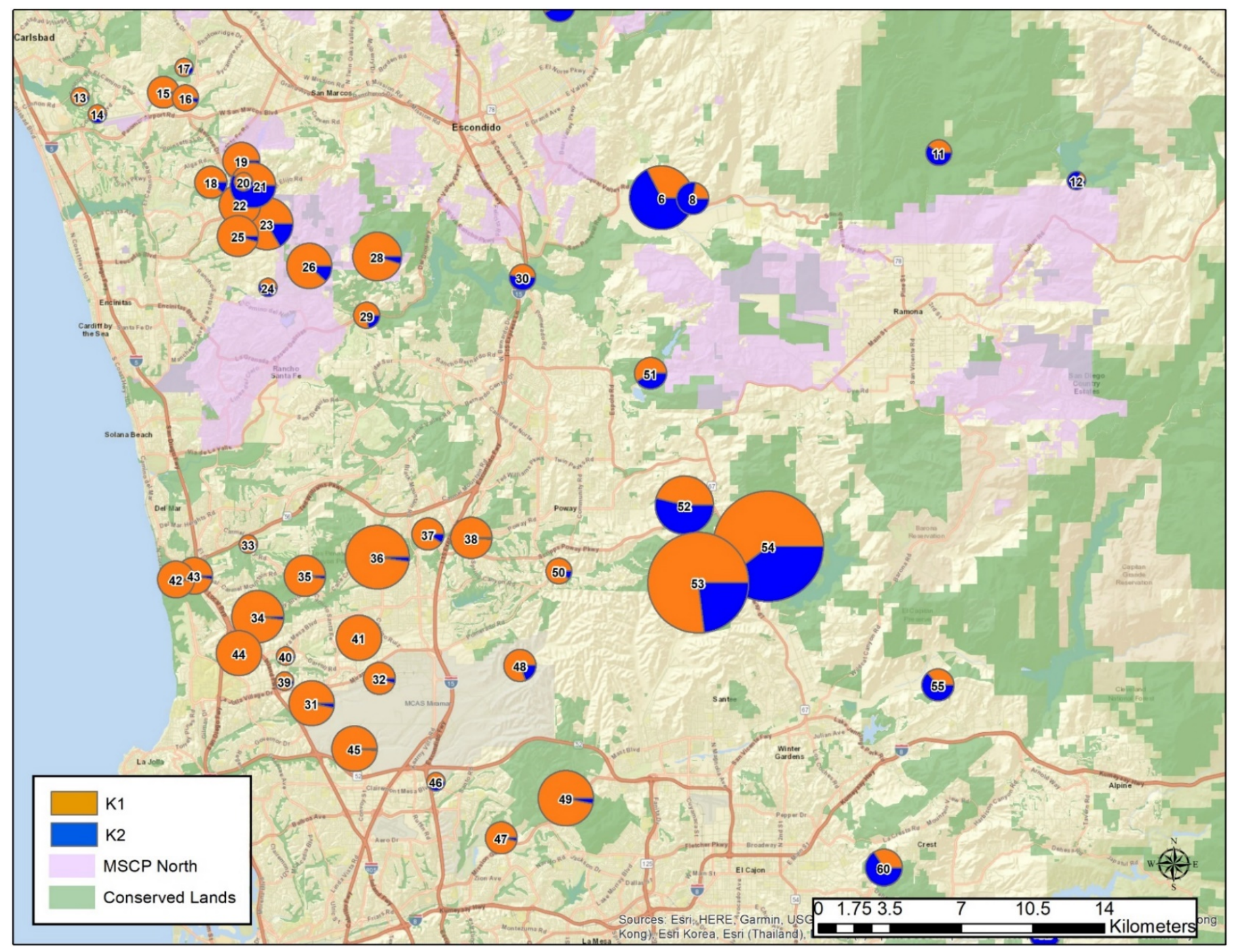

Figure 1.2. Finer detail of central and southern areas of fig. 8, showing the regional San Diego County STRUCTURE analysis. 

For more information concerning the research in this report, contact the Director, Western Ecological Research Center

U.S. Geological Survey 3020 State University Drive East

Sacramento, California 95819

https://www.usgs.gov/centers/werc

Publishing support provided by the U.S. Geological Survey

Science Publishing Network, Sacramento Publishing Service Center 
